\title{
Political connections, political uncertainty and audit fees: Evidence from Pakistan
}

\begin{tabular}{|r|l|}
\hline Journal: & Managerial Auditing Journal \\
\hline Manuscript ID & MAJ-06-2020-2715.R4 \\
\hline Manuscript Type: & Research Paper \\
\hline Keywords: & Politically uncertainty, political connections, audit risk, audit fees \\
\hline \multicolumn{2}{|l}{} \\
\hline
\end{tabular}




\begin{abstract}
Purpose - We examine the association between political connections, political uncertainty, and audit fees. We use various measures of political connections and uncertainty: political connections (civil and military), political events (elections) and a general measure of political stability (i.e., a world bank index).
\end{abstract}

Design/methodology/approach - We measure the association between political connections, political uncertainty, and audit fees. Audit fees reflect auditors' perceptions of risk. We examine auditors' business risk, clients' audit, and business risk after controlling for the variables used in prior audit fee research.

Findings - Results indicate that civil-connected firms pay significantly higher audit fees than non-connected firms owing to the instability of civil-political connections. Military-connected firms pay significantly lower audit fees than non-connected firms owing to the stable form of government. Furthermore, considering high leverage as a measure of clients' high audit risk, and high return-on-assets (ROA) as a measure of clients' lower business risk, we interact leverage and ROA with civil and military connections. Our results reveal that these risks moderate the relationship between political connection and audit fees. Election risk is independent of risk associated with political connections. General political stability reinforces the theme that a stable government results in lower risks.

Originality/value - We combine cross-sectional measures of political uncertainty (civil or military connections) with time-dependent measures (general measures of political instability and elections).

Key Words: Political uncertainty, political connections, audit risk, audit fees. 


\section{Political connections, political uncertainty and audit fees: Evidence from Pakistan}

\section{Introduction}

High quality accounting is important, because of its relationship with economic growth (Bushman et al., 2004; Guenther \& Young, 2000). Hence, one line of research investigates the relation between the institutional structure of a country and the credibility of its financial reporting (Bushman, et al., 2004), or the properties of accounting numbers (Ball et al., 2000; Ball et al., 2003). Gul (2006) extends this line of enquiry by examining the impact of the political economy (i.e., the relation between the government and the economy) on audit pricing. Audit pricing is an appropriate lens to view political economy, because (1) auditing is part of the accounting quality supply chain (International Accounting and Auditing Standards Board (IAASB), 2014); and (2) audit pricing reflects auditor's assessment of business risk (Bell et al., 2001). [1]

In this paper we examine the relation between political connections, political uncertainty, and audit pricing. Audit pricing is expected to capture various risks related to the audit: audit risk (the likelihood of misstatements in the financial statements), clients' business risk (the likelihood of client business failure), and the auditor's business risk (the likelihood of litigation and reputational damage associated with an audit). We hypothesize how political connections and political uncertainty affects the auditor's business risk, as well as the client's audit and business risk. We employ various measures of political uncertainty.

Pakistan's political history is fascinating, because the military (a non-democratic force) has dominated the political landscape of the country since its inception in 1947. Pakistan's militarization since its early days of inception not only weakened political institutions and strengthened the military's role in politics (Cohen, 2002; Siddiqa, 2017; Staniland, 2008) but, eventually, led to the establishment of a strong military business conglomerate (Siddiqa, 2017). Regardless of Pakistan's weak political system, its famous business houses are owned by the political elites of the country (Khwaja \& Mian, 2005). Thus, we identify two types of connected firms, i.e., civil- and military-connected firms.

We hypothesize and find that the auditor's business risk associated with civil politically connected firms is higher than that associated with non-connected firms. Furthermore, civilconnected firms have higher audit and business risk. Whereas the military provides a stable political platform and, hence, the auditor's business risk is lower than it is for non-connected 
firms, as is the client's audit and business risk. We find that political uncertainty related to election years is independent of political connections. However, using a more general measure of political uncertainty (World Bank political instability and absence of violence index), we find that this measure reinforces the lower auditors' business risk associated with political connections in a stable regime.

Existing research typically adopts one of two research designs. To get variation in political connections, one approach is to examine a cross-sectional country-level analysis. The weaknesses of this approach include limited sample sizes, noisy variables, and omitted variables (Miller, 2004). Another approach is to use a single-country analysis that incorporates variables that more cleanly reflect political attributes. For example, Gul (2006) uses a timeseries approach and shows that audit fees of connected Malaysian firms decline after capital controls are introduced, allowing government assistance to politically favoured firms. A major problem of this approach is finding an event or condition where there is variation in the strength of political connections. Our study is interesting, because we examine political connections in both a cross-sectional setting (i.e., a civil versus military political connections) and in a timeseries setting (i.e., the change in political uncertainty).

Our study contributes to three sets of literature. First, we extend the political connection literature by using Pakistan as an exemplar of military business connections. [2] We extend prior research by identifying multiple sources of political connection (i.e., we separate military and civil connections) and examine whether they differ with regard to various audit-related risks, as reflected in audit fees.

Second, we contribute to the literature that examines the business impact of political uncertainty (Jens, 2017; Pastor \& Veronesi, 2012, 2013). This strand of literature notes that there is a positive association between sources of political uncertainty and business risk. We extend this strand of literature by examining election year risk, and a general measure of political uncertainty. We also examine the interactions between uncertainty created by political links and uncertainty created by political events (e.g., elections).

Third, we contribute to the audit fee determinants literature. In a seminal study, Simunic (1980) models the audit fees as comprising two components: audit effort and auditor's potential litigation risk. Subsequent studies have extended the risk component to non-litigation risks, such as auditor reputation (Houston et al., 1999, 2005). Indeed, auditing standards require auditors to consider audit risk, client's financial risk and auditor's business risk.[3] We contribute to this literature by examining the association between auditor's client risk and political uncertainty. 
The remainder of the paper proceeds as follows. The next section reviews the political and business environment in Pakistan. Section 3 reviews the related literature and develops the hypotheses. This is followed by Section 4, which describes the research design issues. Sections 5 and 6 report the results and additional tests and section 7 concludes.

\section{Political and Business Environment in Pakistan}

After its independence in 1947, Pakistan implemented a parliamentary form of democracy. Initially, the civil bureaucracy controlled the country through ex-bureaucrats as important ministers in the political administration. To further strengthen its hold on power, the civilian government involved the armed forces in civilian administrative matters (Fair, 2011), resulting in the emergence of the military as a junior partner in power sharing arrangements (Zaidi, 2005). In 1954, the standing chief was appointed as the defence minister, this appointment not only formalized military's role in politics but paved the way for a military coup in 1958 (Siddiqa, 2017). Appendix 1 outlines the political regime changes since independence of the country up till July 2017. The first military dictator ruled for nearly a decade (1958 to 1969). Since then, Pakistan can be characterised as having two political sources of power: long periods of military control and shorter periods of relatively unstable civilian government.

The military has also intervened in the commercial sector. The military's first commercial project was launched in 1954. Since then, an exponential growth has been documented in military business conglomerate. The military business conglomerate operates in nearly all major sectors of the economy and is in control of country's seven percent of GDP, one third of heavy manufacturing, and 10 percent of private sector assets through these preferentially-treated commercial units (Ali, 2019; Siddiqa, 2017).

While civil and military political economies co-exist, they are not equal. The civil political economy is more unstable. It is exposed to media, judicial, and regulatory scrutiny (Mezzera \& Sial, 2010; Nawaz, 2008; Siddiqa, 2017). The visibility and scrutiny of politicians reduces the stability of political rents extracted by firms connected to the civil administration, or civil-connected firms. In contrast, the military has been a constant source of power, holding the political reigns either directly, through a dictator, or indirectly, through a weak political administration (Zaidi, 2005). Thus, military-connected firms extract consistent political rents. 


\section{Literature Review and Hypotheses}

Resource dependence theory states that organisations are constrained by their institutional and social environment (Pfeffer \& Salancik, 1978). To mitigate the impact of environmental constraints, they attempt to build social capital by using directors as boundary spanners to link the organisation and its environment (Kim \& Cannella Jr., 2008; Pfeffer \& Salancik, 1978). However, this social capital can have adverse consequences, such as high levels of tunnelling, opportunistic related party transactions (Habib et al., 2017), high leverage (Khwaja \& Mian, 2005), poor performance, low analyst forecast accuracy, poor financial reporting quality (Chaney et al., 2011; Faccio, 2006; Faccio \& Parsley, 2009; Rajan \& Zingales, 1998), negative media coverage, and adversary politics (Mezzera \& Sial, 2010; Weinbaum, 1996). These characteristics of politically connected firms might be expected to result in high client audit and business risk, as well as high auditor business risk. However, political connections increase firm value (Fisman, 2001; Hasan et al., 2012). Other benefits offered by political connections include: lower litigation, bailouts during financial hardships (Faccio, 2006, 2010), and profitable government contracts (Goldman, et al., 2009). These characteristics indicate that politically connected companies have lower client as well as auditor business risk (Gul, 2006).

The interaction of these internal and external factors, and accrued benefits or incurred costs make it hard to measure the direct impact of political connections (Habib et al., 2018). Similarly, Preuss and Konigsgruber (2021) report that the existence of both political cost as well as political rents make the financial reporting incentives of politically connected firms hard to conceive. Another approach is to examine indirect indicators, such as the audit fees of politically connected firms (Gul, 2006; Wahab et al., 2011). The connection between audit fees and political connection is particularly useful because auditing standards require auditors to consider not only clients' audit risk (e.g., leverage, the risk of financial restatements) and business risk (risks associated with the client failing), but also auditors' business risk (the risk of litigation or reputation damage). Prior auditing literature suggests that auditors perceived risks of politically connected firms outweigh the accumulated benefits, because of a high likelihood of business failure owing to poor performance, coupled with high leverage, thus, resulting in audit fee premiums. The business failures are particularly visible during the times when the connected politicians are unable to support the firms, either because of political turmoil or a change of government (Aswadi et al., 2011; Bliss \& Gul, 2012; Gul, 2006; Redmayne et al., 2010; Wahab et al., 2015). Furthermore, political connections exacerbate the 
agency problem, thus, auditors exert more effort while conducting the audit engagement of a politically connected company (Tee, 2018). We, therefore, propose the following hypothesis:

H1: Audit fees are higher for politically connected firms relative to non-connected firms.

In developing the hypotheses, and in the empirical analysis, we use non-connected firms as our benchmark. Our hypotheses, therefore, concern the client's audit and business risk as well as the auditor's business risk. Client audit risk is measured by leverage, and business risk is measured by operating performance. The auditors' business risk includes litigation risk (Simunic, 1980) and non-litigation risk, such as reputational damage (Houston et al., 1999, 2005). The Simunic (1980) conceptual audit fee model shows that auditors can reduce total audit risk either by increasing resources (i.e., by increasing audit testing through more audit hours or more experienced auditors), or by charging an audit fee premium. Both responses increase audit fees.

The audit fees outcome of political connections in Pakistan may not be precisely evaluated without segregating them based on the type of their connection i.e., civil versus military connections. There are two characteristics of civil-connected firms that give rise to increased auditor's business risk. The first, relates to political intolerance, humiliation of opponents, and personal attacks on political adversaries as the key characteristics of politics in Pakistan (Belghitar et al., 2016; Weinbaum, 1996). This increases auditor's business risk because the exposure of political rents by political opponents is higher for civil-connected firms than for non-connected firms (National Accountability Bureau (NAB), 2020). Second, civil regimes are more fragile, because they are subject to new elections or are prone to direct military intervention (Bhave \& Kingston, 2010; Fair, 2011). The fragility of civil political regimes increases the probability of political rents being uncovered and legal redress being made against the firm and the auditor. A recent report of the NAB, Pakistan's leading anticorruption organisation to the Supreme Court of Pakistan is one such example. The report identifies 179 mega corruption and cronyism cases that are under trials in different courts of the country, around $22 \%$ of the cases are linked to politicians, including former prime ministers, president, key ministers and even sitting ministers or their business interests (NAB, 2020). [4] Furthermore, the civil-connected firms are expected to have higher audit risk owing to high leverage (Khwaja \& Mian, 2005), and higher business risk because of poor performance (Saeed et al., 2016).[5] Hence, civil-connected firms have higher audit and business risk, and their auditors have a higher business risk. These arguments suggest the following hypothesis: 
H1A: Audit fees are higher for civil-connected firms relative to non-connected firms.

The military in Pakistan has established strong roots in the administrative affairs of the country and has gained the ability to pursue non-military interests during civil as well as military regimes (Fair, 2011; Gregory, 2015; Siddiqa, 2017). However, military intervention in politics and business is not unique to Pakistan. For example, military connected firms in Indonesia engage low quality auditors and report poor quality financial reports (Harymawan, 2020) but avail cheaper bank loans (Harymawan, 2018). In Pakistan, preferential treatment and easy access to financing are available to military-connected firms across civil as well as military regimes (Ali, 2019; Siddiqa, 2017). For example, Fauji Fertilizer (a stock exchange listed firm) received a natural gas subsidy worth $\$ 18.97$ million in 2006 alone. Army Welfare Trust (investment arm of Pakistan Army) received \$93 million bailout package in 2011 (the third such package since 1995) (Blom, 2011). These figures indicate that military-connected firms are less reliant on raising more debt (lower audit risk). Similarly, Senator Farhatullah Babar of the Pakistan People's Party, the key opposition party, during an important senate session, promulgated that military-connected firms are awarded profitable government contracts without following due bidding process. Furthermore, government loans owing to such firms are written off without adopting any transparent accounting procedures, resulting in crony capitalism, but better performance for military-connected firms (lower business risk) (Khan, 2017).[6] Furthermore, through their financial and coercive powers the military restrict scrutiny of themselves or their business interests from print, electronic and social media (Aslam, 2015; NAB, 2020; Pintak et al., 2016; Siddiqa, 2017). The recent report of the NAB is an example of this poor scrutiny of military and its business interests. The report contains less than $2 \%$ of the cases against military officers, and none against the military business empire (NAB, 2020). From an auditor's perspective, the poor regulatory, media and public scrutiny, of military-connected firms, results in reduced auditor business risk. In summary, militaryconnected firms have lower audit risk, lower business risk as well as lower auditor business risk than non-connected firms, leading to lower audit fees. These arguments suggest the following hypothesis:

H1B: Audit fees are lower for military-connected firms relative to non-connected firms. 
Based on the above premise, we argue that the two types of politically connected firms identified in this study have varying degrees of visibility, enmity, and legal implications. Thus, it is expected that these firms will use different channels of rent extraction. For example, civilconnected firms will use indirect and less visible channels of political rents, such as paying lower taxes (Sadiq et al., 2019), and having higher leverage (Saeed et al., 2015) which increases clients' audit risk. However, civil-connected firms have poor performance (Saeed et al., 2016), and higher levels of default on loans (Khwaja \& Mian, 2005) which increases clients' business risk. Taken together, civil connected audit clients have both high audit and business risk.

Military-connected firms will use direct channels of rent extraction such as hard cash (subsidies) during financial distress (Blom, 2011) and profitable government contracts on preferential terms (Khan, 2017) which result in higher profits i.e., lower business risk. These arguments further indicate that it will be easy for military connected firms to extract direct political rents such as subsidies and bailouts during financial hardships, leading them to have less reliance on leverage i.e., lower audit risk. Thus, the interplay of less leverage (lower audit risk) and better performance (lower business risk) of military connected firms will affect auditor pricing decisions. Based on these arguments, we suggest the following hypotheses.

$\boldsymbol{H} \boldsymbol{2} \boldsymbol{A}$ : High leverage and poor firm performance of civil-connected firms will increase audit fees.

$\boldsymbol{H} 2 \boldsymbol{B}$ : Low leverage and better firm performance of military-connected firms will decrease audit fees.

Economists consider that political uncertainty is a severe malaise that is detrimental to economic performance. Political uncertainty is likely to shorten policymakers' horizons (Aisen \& Veiga, 2013). At the firm-level, political uncertainty increases equity trading costs (Eleswarapu \& Venkataraman, 2006), corporate risk-taking behaviour (Boubakri et al., 2013), and the probability of default owing to policy reversals (Gilchrist et al., 2014). Political uncertainty also reduces firms' incentives to invest in value-creating projects (Glaeser \& Shleifer, 2003; Julio \& Yook, 2012).

Prior literature documents that elections are a source of significant political uncertainty. Political uncertainty caused by elections results in dampened asset prices (Pastor \& Veronesi, 2012, 2013) and reduced investment by firms (Jens, 2017). The negative consequences of political uncertainty are more pronounced in countries with higher levels of corruption, less transparency, and marked state involvement in the economy. Furthermore, the adverse 
outcomes of political uncertainty are visible during the election year, as well as the year preceding the general elections (Boutchkova et al., 2012). Kelly et al. (2016) and Pastor and Veronesi $(2012$, 2013) conclude that political uncertainty caused by elections increases business risk. Recent auditing literature documents that besides business risk, political and economic policy uncertainty also results in more audit efforts and, hence, an increase in audit fees (Yun \& Chun, 2021). Hence, we hypothesize as follows:

H3: There is a positive association between political uncertainty and audit fees.

The chance of business failure of civil-connected firms increases during election periods because politicians cannot rely on financial assistance after the election. The ability of the incumbent civilian governments to rescue failing companies during periods of political uncertainty is hampered because of the possibility of a new incoming government. Thus, elections increase business risk for both client and auditor for civil-connected firms relative to non-connected firms.

The military's ability to assist its connected firms financially is less affected by political uncertainty. High political uncertainty in countries with weak political institutions reduces contract enforcement (Bhattacharyya \& Hodler, 2014). This weak enforcement of contracts will make it easy for the military to mount pressure on politicians to funnel resources directly to their commercial ventures. This is evident in the fact that the Pakistan military's business empire recorded exponential growth during weak and unstable civil regimes (Siddiqa, 2017). Thus, military-connected firms are less affected by political uncertainty. We, therefore, develop the following hypotheses:

$\boldsymbol{H 3 A}$ : The positive association between political uncertainty and audit fees is stronger for civilconnected firms relative to non-connected firms.

H3B: The positive association between political uncertainty and audit fees is weaker for military-connected firms relative to non-connected firms.

\section{Research Design Issues}

\subsection{Definition of Political Connection}

Different methods are used in the literature to identify political connections across jurisdictions. These include having: a geographical affiliation (Faccio \& Parsley, 2009), a politician (or close relative) as shareholder (Fisman, 2001; Gul, 2006; Johnson \& Mitton, 2003; Wahab et al., 2015), politician (or close relative) as top officer (Faccio, 2006; Fan et al., 2007; 
Su et al., 2013), or politicians or government officials as employees (Bona-Sánchez et al., 2014; Jackowicz et al., 2014; Niessen \& Ruenzi, 2010), and receiving campaign contributions (Blau et al., 2013; Claessens et al., 2008; Correia, 2014; Ferguson \& Voth, 2008; Ramanna \& Roychowdhury, 2010).

In Pakistan, the identification of politically connected firms through major shareholders or the board of directors is more meaningful for the following reasons. First, major shareholders are normally the controlling shareholders, and are actively involved in decision-making. Second, the board of directors are important from a governance perspective. Following Faccio (2006: p. 6), we use the following definition to identify political connections:

A firm is identified as having a civil connection $(\mathrm{CCON})$ if at least one of its large shareholders (top 5 percent) or one of its top officers (CEO, president, vice-president, chairman, or secretary) is a member of parliament, a minister, or closely related to a top politician or party.[7] A firm is identified as having a military connection (MCON) if at least one of its large shareholders or top officers is a retired or serving military officer, or military (as an institution) is amongst the top 5 percent shareholders.[8] Firms that are neither civil- nor military-connected are labelled as non-connected ( $\mathrm{NCON})$.

\subsection{Identification of Political Connection}

Two datasets have been created to identify politically connected companies. The first dataset contains the names and other details (political affiliation, number of votes obtained, position held, etc.) of the members of the upper house of the parliament (Senate), the lower house of the parliament (National Assembly), and four provincial assemblies for the general elections held in 2002, 2008 and 2013. The data are retrieved from the election commission of Pakistan and parliament of Pakistan websites. The second dataset contains the names of directors and large shareholders of Pakistan Stock Exchange (Karachi floor) listed companies. The data are retrieved from the State Bank of Pakistan. The two datasets are then matched to identify companies connected to the politicians through having a member of parliament as either a board member or a large shareholder.[9]

We identify military connections through identifying board members as currently serving or retired military personnel. Military designations (Capt., Maj., Col., and Gen.) are used in the search criteria. Retired or serving military officers use their military designations as a symbol of power and prestige. We identify military connections through the military's institutional ownership: the words "Fauji, Bahria, Shaheen, and Army" are used in the search criteria.[10] 
Audit and governance-related variables are collected manually from audited financial statements. The remaining variables are retrieved from the "financial information of nonfinance companies listed on the Karachi Stock Exchange" issued by the Statistics and Data Warehouse Department of the State Bank of Pakistan.[11] This department is responsible for collection, compilation, and dissemination of statistics on economic, financial, and monetary aspects of the economy. As it follows International Monetary Fund (IMF) dissemination standards, the data is regarded as being highly reliable.

\subsection{Empirical Models}

We use the following OLS regression model to test H1:

$L n A F=\alpha+\beta 1 P C O N+\beta_{k} C O N T R O L S+$ IndustryFE + YearFE $+\varepsilon$

Where $L n A F$ is the natural logarithm of audit fees in thousands. PCON equals 1 for politically connected firms and 0 otherwise. We expect a significant positive coefficient on $P C O N$. The definition and interpretation of the control variables (CONTROLS) is described below. IndustryFE and YearFE are industry and year fixed effects, respectively.

We use the following model to test hypotheses H1A and H1B:

$$
L n A F=\alpha+\beta_{1} C C O N+\beta_{2} M C O N+\beta_{k} C O N T R O L S+\text { IndustryFE }+ \text { YearFE }+\varepsilon . .
$$

Where $C C O N$ equals one for civil-connected firms, zero otherwise, and $M C O N$ is equal to one for military-connected firms, zero otherwise. The non-connected firms are the referent dummy in the model, captured in the intercept. A significant positive coefficient is expected on $\beta_{1}$ and a significant negative coefficient is expected on $\beta_{2}$.

To test $\mathrm{H} 2 \mathrm{~A}$ and $\mathrm{H} 2 \mathrm{~B}$, we expand Equation (2.1) above as follows:

$$
\begin{aligned}
& \text { LnAF }=\alpha+\beta_{1} C C O N+\beta_{2} M C O N+\beta_{3} L E V+\beta_{4} R O A+\beta_{5} C C O N * L E V+\beta 6 \\
& \text { CCON * ROA }+\beta 7 M C O N * L E V+\beta 8 M C O N * R O A+\beta k O T H E R \_C O N T R O L S+ \\
& \text { IndustryFE +YearFE }+\varepsilon \ldots \ldots \ldots \ldots \ldots . .(2.2)
\end{aligned}
$$

Where $C C O N^{*} L E V, C C O N^{*} R O A, M C O N^{*} L E V$, and $M C O N^{*} R O A$ are the variables of interest. Considering high leverage as an indication of high audit risk, and high ROA as an indication of low business risk, we expect a significant positive (negative) coefficient on $C C O N^{*} L E V$ and $M C O N^{*} L E V\left(C C O N^{*} R O A\right.$ and $\left.M C O N^{*} R O A\right)$.

To test $\mathrm{H} 3$, we include ELECDUM in the regression model:

$$
L n A F=\alpha+\beta 1 E L E C D U M+\beta_{k} C O N T R O L S+\operatorname{Industry} F E+\varepsilon
$$


ELECDUM is a dummy variable representing political uncertainty. There is evidence of an association between electoral outcomes and the accounting information in financial statements (Bradbury \& Scott, 2015; Ramanna \& Roychowdhury, 2010). During the period of our sample (2003-2014), general elections were held in 2008 and 2013. We code ELECDUM equal to one in the election year and the year before (see Boutchkova et al., 2012) and zero otherwise (i.e., 2007, 2008, 2012, and $2013=1$ and the rest of the sample years $=0$ ). H3 predicts a significant positive coefficient on ELECDUM indicating that higher political uncertainty increases audit fees. As ELECDUM is defined in terms of years, we do not include year-fixed effects.

Hypothesis $\mathrm{H} 3 \mathrm{~A}$ and $\mathrm{H} 3 \mathrm{~B}$ examine the moderating effect of political uncertainty on the audit fees of $C C O N$ and $M C O N$ relative to non-connected firms. Hypotheses H3A and H3B are tested by including two interaction terms (CCON*ELECDUM and $\left.M C O N^{*} E L E C D U M\right)$ :

$L n A F=\alpha+\beta_{1} C C O N+\beta_{2} M C O N+\beta_{3} E L E C D U M+\beta_{4} C C O N * E L E C D U M+\beta 5$ $M C O N * E L E C D U M+\beta_{k}$ CONTROLS + IndustryFE $\left.+\varepsilon \ldots \ldots \ldots \ldots . . . .2 .2\right)$

In Equation (3.2), $\beta_{1}$ and $\beta 2$ are the respective slope coefficients on CCON and MCON firms when $E L E C D U M=0 . \beta 3$ estimates the association of the general effect of political uncertainty $(E L E C D U M)$ on audit fees. The coefficient on the interaction terms ( $\beta 4$ and $\beta 5)$ assess the association of political uncertainty on CCON and MCON firms. H3A predicts a significant positive coefficient on $C C O N^{*} E L E C D U M$, while $\mathrm{H} 3 \mathrm{~B}$ predicts a significant negative coefficient on $M C O N^{*} E L E C D U M$.

Our objective is to build a parsimonious audit fee model, and we choose control variables that are relatively standard in the literature to capture audit risk and client business risk. Firm size (SIZE) is measured as the natural logarithm of total assets (in millions). Financial risk is measured by dividing long term debts over total assets ( $L E V)$. Profitability $(R O A)$ is calculated as net profits divided by total assets. Audit complexity is measured by the level of accounts receivables $(R E C)$ and inventory $(I N V)$, scaled by total assets. Auditor quality is measured by including a dummy variable, (one for Big Four audit firms, zero otherwise). OPIN is equal to one if the audit report is modified and zero if it is unqualified. Audit committee $(A C O M)$ and board size $(B S I Z E)$ variables are included to capture the impact of the corporate governance mechanism. Discretionary accruals $(D A C)$ is included as an additional control for audit risk. [12]

In Equations (3.1) and (3.2), we examine the impact of election year uncertainty on audit fees. The election year indicator variable is simply a reconfiguration of the year-fixed 
effects. Therefore, in these models we drop the year-fixed effects but include two continuous variables to capture possible omitted effects by year: (1) INFLATAION and (2) GDP_GROWTH. INFLATION is the percentage rate of inflation in the current year, while GDP_GROWTH represents the percentage growth in gross domestic product in the current year compared with the previous year. Both these variables are retrieved from the official website of the World Bank.

\subsection{Test Period and Sample}

The political history of Pakistan is interesting in the sense that the military has remained dominant in the political affairs of the country since its inception in 1947 . The country has passed through four successful military regimes (see appendix I). Each successful military intervention in Pakistan resulted in shaking the political structure, increasing political instability, and further strengthening the financial and political role of the military (Fair, 2011). We use a sample from 2003 to 2014. Table 1 reports the results of the sample selection procedures. The maximum number of observations is 2,208. However, information on audit fees and other data is missing for 953 firm-year observations, making a final sample of 1,255 firm-year observations.

\section{[Insert Table 1 here]}

Table 2 reports the distribution of observations by year (Panel A), sector (Panel B) and political connection. NCON is the largest group (with 747 firm-year observations), followed by CCON (311 firm-year observations), and MCON (197 firm-year observations). NCON is the reference group and is comprised of firms without any clearly traceable connections to politicians or military. Non-connected firms opt to remain non-connected either because of the political cost (Mezzera \& Sial, 2010; Weinbaum, 1996), the dilution of reliance on government for access to finance after the liberalization of Pakistan's economy in the early 2000s, or the existence of a strong de facto economy (Manes, 2013). Our matching mechanism results in four (4) companies with dual connections (political as well as military). Firms with dual connections have been excluded from the analysis. There is a reasonable spread of civil- and military-connected firms across most industries. Nevertheless, we use industry indicator variables to control for possible industry effects.

\section{[Insert Table 2 here]}




\section{Results}

Descriptive statistics are reported in Table 3. We undertake univariate tests for differences between non-connected and politically connected firms. We report a nonparametric Mann-Whitney U test for continuous variables and Chi-square tests for indicator variables. CCON firms, compared to NCON firms are more highly leveraged, have lower profitability $(R O A)$, are less likely to engage a $B I G 4$ auditor, and are less likely to have a qualified audit opinion. MCON firms, compared to NCON firms, have lower audit fees and are less likely to engage a $B I G 4$ auditor.

\section{[Insert Table 3 here]}

Table 4 reports the correlation matrix which shows that $M C O N$ have a significant negative correlation, while ELECDUM, SIZE, ROA, REC, INV, BIG4, and $|D A C|$ have significant positive correlations with audit fees. To further investigate the multicollinearity bias, we calculated variance inflation factors (VIF), which are far below 10 (the highest one being 1.49 and the mean 1.21), indicating that the regression estimation is not biased because of any multicollinearity issue.

\section{[Insert Table 4 here]}

Table 5 reports the OLS regression results. Panel A reports the regression results for political connection and audit fees. Column (1) shows that the coefficient on PCON is not significant indicating that political connections do not affect auditors pricing decisions, this result does not support H1. However, these results may be misleading if we do not consider the nature of the political connections. To mitigate the impact of this serious potential problem, we split the politically connected sample into two groups, i.e., civil- versus military-connections, by replacing the PCON dummy with two dummies $C C O N$ and $M C O N$ and rerun the regression. In Column 2, the coefficient on CCON is positive $(0.085)$ and significant $(p<0.10)$. Thus, the result supports hypothesis $\mathrm{H} 1 \mathrm{~A}$, and indicates that $C C O N$ firms pay higher audit fees relative to non-connected firms. The coefficient on MCON is negative $(-0.247)$ and highly significant ( $\mathrm{p}<0.01$ ), supporting hypothesis H1B that MCON firms pay lower audit fees relative to NCON firms. In terms of economic significance, CCON firms pay 8.9 percent $\left(=\left(e^{0.085}-1\right)\right)$ higher audit fees than NCON firms while the audit fees of MCON firms are 28 percent lower than NCON firms.

Column 3, tests hypotheses H2A and H2B. It is expected that auditors will take the client's audit risk ( $L E V)$ and business risk $(R O A)$ into account while pricing the client. In column 3, the coefficient on CCON becomes insignificant, while the coefficient on MCON 
remains negative and significant. Results for the interaction effect $C C O N^{*} L E V$ is positive $(0.353)$ and significant $(\mathrm{p}<0.10)$ while the coefficient on the interaction effect $C C O N^{*} R O A$ is insignificant, thereby, partially supporting H2A. The two results in conjunction indicate that, in relation to $C C O N$ firms, auditors consider a client's high leverage as the key trigger of their audit risk. Similarly, the result on the interaction term $M C O N^{*} L E V$ is not significant, indicating that auditors do not consider high leverage in $M C O N$ firms as being an indication of high audit risk. The result for the interaction term $M C O N^{*} R O A$ is negative $(-0.747)$ and significant $(\mathrm{p}<0.05)$, indicating that auditors consider highly profitable MCON as having low business risk. These results in conjunction support $\mathrm{H} 2 \mathrm{~B}$.

The results for control variables are in conformity with the findings of prior research (Gul, 2006). Firm size is the most significant variable affecting audit fees. Other variables significantly affecting audit fees include $R O A, R E C, I N V$, and $B I G 4$. The adjusted $\mathrm{R}^{2}$ of Models is around $70 \%$.

\section{[Insert Table 5, Panel A here]}

Table 5 Panel B reports the OLS regression results for political uncertainty. Column 1 reports regression results to test the impact of political uncertainty on audit fees. The coefficient on ELECDUM is positive $(0.188)$ and significant $(\mathrm{p}<0.01)$. The positive association between election years and audit fees supports H3. In quantitative terms, election years increase the audit fees by around 20 percent. Column 2 tests Hypothesis H3A and H3B. However, the coefficients on the interaction terms $\left(C C O N^{*} E L E C D U M\right.$ and $\left.M C O N^{*} E L E C D U M\right)$ are not significant. This indicates that in terms of audit fees, election year effects are independent of political connection. These results do not provide support for our directional hypotheses, H3A and $\mathrm{H} 3 \mathrm{~B}$.

\section{[Insert Table 5, Panel B here]}

\section{Additional Analysis}

\subsection{Political instability as an indicator of political uncertainty}

As another measure of political uncertainty, we use the "Political Instability and Absence of Violence Index" (PIindex) created by the World Bank and replace ELECDUM. This index, ranging from +2.5 to -2.5 , measures the level of political instability and violence in a country. Higher scores represent the more stable political environment. We, therefore, multiply the index by -1 , so that positive values imply high political instability. Consistent with $\mathrm{H} 3$, it is expected that PIindex will increase overall business risk and auditor business risk. Hence, 
auditors will either undertake more tests, increase the level of auditor expertise, or charge a fee premium. All these responses increase audit fees.

Table 5, Panel B, column 3 reports OLS regression results including PIindex. The results for this column are similar to those of Column 2. The coefficient on the measure of political uncertainty $($ PIindex) is positive $(0.966)$ and significant $(\mathrm{p}<0.01)$, hence, it supports $\mathrm{H} 3$, i.e., audit fees have a positive association with political uncertainty. The results in column 4 , which include the political uncertainty and political connection interaction terms, differ considerably from those in column 2. Neither the political connections nor the interaction terms are significant. This suggests that when general levels of political uncertainty are high, the impact of auditor business risk on audit fees for civil-connected firms is the same as for non-connected firms. One possible interpretation is that, if this political risk is high, then it "swamps" audit risk or renders it insignificant.[13]

\section{[Insert Table 5, Panel B here]}

\subsection{Test of Endogeneity: Propensity Score Matching (PSM) Techniques}

A firm's decision to get politically connected is not random, and unobservable factors that affect this decision may also be associated with firm-level audit fees. Stated another way, there is a possibility that certain innate features of firms may lead to an increase in both the probability of forming political connection and audit fees. We use propensity score matching (PSM) methodology (Rosenbaum and Rubin, 1983, 1985) to mitigate this concern. In our setting, the basic approach to PSM is to first model the probability of forming political connections on the underlying firm-specific determinants. We match the firms from a treatment group (politically connected/election years), with firms from a control group (nonconnected/non-election years). Importantly, the inclusion of the firm-specific determinants ensures a proper balance between treated and untreated subjects in the matched sample, which is a key criterion for PSM (Austin, 2011). Table 6, Panel A reports the covariates matching for the difference between the means of the treated and control groups. Results indicate that, with the exception of $I N V$ for the CCON sample, all other variables are insignificant, thereby, confirming proper matching.

\section{[Insert Table 6, Panel A here]}

Panel B reports the regression results for politically connected groups. Column 1 reports the first stage regression results. As expected, the coefficient on $L E V$ is positive and significant $(1.019, \mathrm{p}<0.01)$ while the coefficient on $R O A$ is negative and significant $(-0.094$, $\mathrm{p}<0.01$ ), indicating that CCON firms are highly levered and poor performers. Untabulated 
results indicate that CCON firms tend to engage non-Big 4 auditors and have smaller board size. Column 2 reports the second stage regression results, which indicate that the coefficient on $C C O N$ is positive and significant $(0.109, \mathrm{p}<0.05)$, thereby, supporting H1A. Column 4 reports the first stage regression results where the coefficient on $L E V$ is negative but not significant while the coefficient on $R O A$ is positive and significant $(0.816, \mathrm{p}<0.10)$ indicating that MCON firms are less levered and have better performance than the control group. Column 5 reports a negative $(-0.327)$ and significant $(\mathrm{p}<0.01)$ coefficient on $M C O N$ which supports H1B. These results are in conformity with the baseline regression results reported in Table 5, Panel A. However, the results in column 3 on $C C O N^{*} L E V$ and $C C O N^{*} R O A$, as well as in column 6 on $M C O N^{*} L E V$ and $M C O N^{*} R O A$, are not significant. Hence, H2A and H2B are not supported. Column 8 reports that the coefficient on ELECDUM is positive (0.196) and significant $(\mathrm{p}<0.01)$, thereby, supporting H3. The coefficients on the interaction terms: $C C O N^{*} E L E C D U M$ and $M C O N^{*} E L E C D U M$ in column 9 are insignificant. H3A and H3B, therefore, are not supported. However, these results are in conformity with the baseline regression results reported in Table 5, Panel B. Results for other control variables (untabulated) in Table 6 remain in conformance with Table 5. These results indicate that our results remain robust to any endogeneity concerns.

\section{[Insert Table 6, Panel B here]}

\subsection{Heckman's Test for Self-Selection Bias}

We also perform the Heckman (1979) self-selection test to mitigate the endogeneity concern mentioned above. To run the Heckman (1979) test, we follow previous literature (Faccio, 2006, 2010; Habib et al., 2017) and run the following first stage probit model:

$$
P C O N=\mathrm{\gamma}_{1} C A P I T A L+\mathrm{\gamma}_{K} C O N T R O L S+\text { Industry } F E+\varepsilon \ldots \ldots .
$$

Lennox et al. (2012) argue that it is important to impose exclusion restrictions in implementing the Heckman two-stage regression. In other words, we need at least one variable in the first-stage model that affects audit fees through its effects on political connections only. We, therefore, follow prior research which suggests that firms located in capital cities are more likely to form political connections (Agrawal \& Knoeber, 2001) and include CAPITAL, a dummy variable coded 1 for firms located in the capital city i.e., Islamabad, and 0 otherwise. We use all other control variables used in the baseline regression model to run the first stage probit model. We obtain the Inverse Mills Ratio (IMR) from Equation (4) above and include it as an additional variable in the second stage regression model. Table 
7, column 1 reports regression results after implementing the Heckman procedure. Column 1 reports that the coefficient on CAPITAL is positive (1.145) and highly significant $(\mathrm{p}<0.01)$, indicating that politically connected firms are largely located in the capital city. Furthermore, the coefficients on IMR across all columns remain insignificant, indicating the validity of our estimation procedure. Column 2 shows that the coefficient on $C C O N$ is positive but insignificant, and that on $M C O N$ is negative and significant, thus, supporting $\mathrm{H} 1 \mathrm{~B}$. The coefficient on $C C O N^{*} L E V$ in column 3 is positive and significant (coefficient $0.353, \mathrm{p}<0.05$ ) while the coefficient on $C C O N^{*} R O A$ is insignificant, as is consistent with the Panel A, Table 5 results. Similarly, the coefficient on $M C O N^{*} L E V$ is not significant, but the coefficient on $M C O N^{*} R O A$ is negative (-0.748) and significant $(\mathrm{p}<0.05)$, as reported in the baseline regression results. Results for other control variables (untabulated) indicate that the coefficients on SIZE, LEV ROA, INV, Big 4 auditors are positive and significant. Column 4 reports a significant positive coefficient on $\operatorname{ELECDUM}(0.188, \mathrm{p}<0.01)$, thereby, supporting H3. However, none of the interactive variables in column 5 has a significant coefficient: results consistent with the baseline regression results reported in Table 5. Similarly, the results reported in column 6 show a significant positive coefficient on PIindex $(0.950, \mathrm{p}<0.01)$ supporting $\mathrm{H} 3$, untabulated results for column 6 report that the coefficients on SIZE, ROA, REC, INV, and Big 4 auditors are positive and significant as reported in previous columns. None of the coefficients on the interaction terms are significant in column 7. The results reported in Table 7 conclude that our baseline regression results are not affected by any serious self-selection bias.

\section{[Insert Table 7 here]}

\section{Conclusion}

In this paper we examine the relation between political connections, political uncertainty and audit fees. Audit fees reflect the audit risk, the client's business risk, and the auditor's business risk. The auditor's business risk includes risks such as litigation and reputation damage arising from association with a client. The Simunic (1980) model suggests two audit responses to increased risk: (1) increased testing and (2) increased audit fee premium. Hence, we use audit fees to assess political risk by controlling for variables used in prior research.

We use various measures of political connections and political uncertainty in both a cross-sectional and a time-series research design. First, we examine the uncertainty 
surrounding political connections. We distinguish between firm connections with civil politicians and with the military. In our setting (Pakistan) we hypothesize and find, that the civil connections are less stable and, therefore, will increase auditor business risk as well as client audit and client business risk, resulting in high audit fees. On the other hand, the military is a stable political force, giving rise to lower risk (audit fees) for military-connected than for non-connected firms.

In addition, we conduct a time-series investigation of auditors' response to political uncertainty created by elections and by a general measure of political uncertainty. We interact the time-dependent measures of political uncertainty with the political connections. In our setting, the election year risk results in a general increase in audit fees. This risk is independent of the firm's political connections. On the other hand, our measure of general political risk interacts with military political connections. This reinforces the expectation that, in our setting, the stable political platform of the military reduces audit and business risk. 


\section{Notes}

1. Other auditing research approaches are to examine the appointment of high-quality auditors (e.g., Bliss \& Gul, 2012; Guedhami et al., 2014, Habib et al., 2017) or the political connections of the auditors (Cheng et al., 2015).

2. The impact of military business is not restricted to totalitarian military states. Military business refers to military capital that is used for the benefit of the military fraternity. It exists in various forms. In countries such as the U.S. and the UK it operates in partnership with the civilian corporate sector and the government. In countries such as Iran, Cuba and China it operates through partnership with the dominant ruling party or leader. In Turkey, Indonesia, Thailand and Pakistan the military is the sole diver of military business (Siddiqa, 2017).

3. For descriptions of these risks, see the literature review by DeFond and Zhang (2014, p. 296).

4. The Audit Oversight Board, Pakistan's premier auditor regulatory body, has barred the engagement partner of KPMG from auditing public interest companies for one year, and also imposed a penalty of PKR 3.5 million (around 23,000 USD) on the leading audit firm for not fulfilling its obligation while auditing one of the companies connected with the ousted leader of Pakistan Tahreek Insaf, the current ruling party. (Daily: The News, retrieved from: https://www.thenews.com.pk/print/846586-clarification)

5. Univariate results show that civil-connected firms are highly levered and have poor performance (ROA) compared with non-connected firms. Unreported multivariate results endorse these findings. For example, the coefficient on $C C O N$ is positive and significant $(0.079, \mathrm{p}<0.01)$ when $L E V$ is regressed on $C C O N$ and other control variables. The corresponding coefficient on $C C O N$ is negative and significant $(-0.23, \mathrm{p}<005)$ when $R O A$ is regressed on $C C O N$ and other control variables. These results indicate that CCON firms have a higher audit risk.

6. Univariate results reported in the paper show that military-connected firms are not more levered than nonconnected firms and perform better. Unreported multivariate results show that the coefficient on $M C O N$ is not significant when leverage is regressed on $M C O N$ and other control variables while the coefficient on $M C O N$ is positive and significant $(0.020, \mathrm{p}<0.10)$ when $R O A$ is regressed on $M C O N$ and other control variables. These results indicate that MCON firms have lower business risk compared with their nonconnected counterparts.

7. Closely related means wife, son, father, brother, or an identified business partner.

8. Faccio (2006) uses the top 10 percent of shareholders, but we use the top 5 percent threshold, for the reason that most of the Pakistan Stock Exchange listed firms disclose details of their top 5 percent shareholders in the annual reports.

9. Names of the board of directors and large shareholders are matched with the members of parliaments.

10. These are names of the investment arms of the military.

11. This report contains firm- and industry-level financial information, including income statement, balance sheet, cash flow statement, and key financial ratios. The report also has key non-financial information, including board of directors, auditors and other significant matters for all listed firms. The report is issued on annual basis.

12. We estimate the level of discretionary accruals (DAC) using the cross-sectional Jones model (Jones, 1991). We use residuals of the following model as a level of discretionary accruals. We use the absolute value of $\mathrm{DAC}(|\mathrm{DAC}|)$ in our regression specifications.

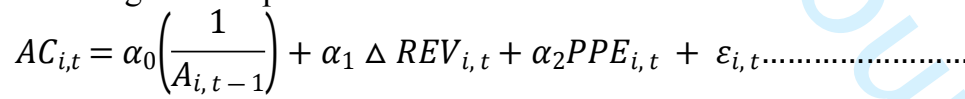

where

$$
\begin{array}{ll}
\mathrm{AC}_{\mathrm{i}, \mathrm{t}}= & \begin{array}{l}
\text { Accruals in year t scaled by lagged total assets. Accruals equal the change in current assets } \\
\text { (excluding cash and cash equivalents) minus current liabilities (excluding short term debt) }
\end{array} \\
& \begin{array}{l}
\text { minus depreciation for the year. } \\
\mathrm{A}_{\mathrm{i}, \mathrm{t}-1}=
\end{array} \\
\Delta \mathrm{REV}_{\mathrm{i}, \mathrm{t}}= & \begin{array}{l}
\text { Lagged total assets. } \\
\text { Current year revenue minus last year's revenue scaled by lagged total assets. }
\end{array} \\
\mathrm{PPE}_{\mathrm{i}, \mathrm{t}}= & \text { Property plant and equipment in year t scaled by lagged total assets. } \\
\varepsilon_{\mathrm{i}, \mathrm{t}}= & \text { Error term. }
\end{array}
$$

13. Untabulated results for regressions with interaction terms $C C O N^{*} L E V, C C O N^{*} R O A, M C O N^{*} L E V$, and $M C O N^{*} R O A$ (columns 4 to 7 ) remain the same as the baseline results. 


\section{References}

Agrawal, A., and Knoeber, C.R. (2001), "Do some outside directors play a political role?", Journal of Law and Economics, Vol. 44, pp. 179-198.

Aisen, A., and Veiga, F. J. (2013), "How does political instability affect economic growth?", European Journal of Political Economy, Vol. 29, pp.151-167.

Ali, A. (2019), "Uneasy co-existence: Pakistan's national security approach and the post-cold war security environemnet", (Doctoral desertation), University of Otago, Dunedin, New Zealand

Aslam, R. (2015), " Media politics and the threats to journalists in Pakistan", Pacific Journalism Review, Vol. 21 No. 1, pp. 177-194.

Aswadi, E., Zain, M. M., and James, K. (2011), "Political connections, corporate governance and audit fees in Malaysia", Managerial Auditing Journal, Vol. 26 No. 5, pp. 393-418.

Austin, P. C. (2011), "Optimal caliper widths for propensity-score matching when estimating differences in means and differences in proportions in observational studies", Pharmaceutical Statistics, Vol. 10, pp. 150-161

Ball, R., Kothari, S. P., and Robin, A. (2000), "The effect of international institutional factors on properties of accounting earnings", Journal of Accounting and Economics, Vol. 29 No. 1, pp. 151.

Ball, R., Robin, A., and Wu, J. S. (2003), "Incentives versus standards: Properties of accounting income in four East Asian countries", Journal of Accounting and Economics, Vol. 36 No.1-33, pp. 235270.

Belghitar, Y., Clark, E., and Saeed, A. (2016), "Political connections and corporate financial decision making", Unpublished manuscript. Retrieved from https://ssrn.com/abstract=2821123.

Bell, T. B., Landsman, W. R., and Shackelford, D. A. (2001), "Auditors' perceived business risk and audit fees: Analysis and evidence", Journal of Accounting Research, Vol. 39 No. 1, pp. 35-43.

Bhattacharyya, S., and Hodler, R. (2014), "Do natural resource revenues hinder financial development? The role of political institutions.", World Development, Vol. 57, pp. 101-113.

Bhave, A., and Kingston, C. (2010), "Military coups and the consequences of durable de facto power: the case of Pakistan", Economics of Governance, Vol. 11 No. 1, pp. 51-76.

Blau, B. M., Brough, T. J., and Thomas, D. W. (2013), "Corporate lobbying, political connections, and the bailout of banks", Journal of Banking \& Finance, Vol. 37 No. 8, pp. 3007-3017.

Bliss, M. A., and Gul, F. A. (2012), "Political connection and cost of debt: Some Malaysian evidence", Journal of Banking \& Finance, Vol. 36 No. 5, pp. 1520-1527.

Blom, E. (2011), "Paksitan: Coercion and capital in an insecure state", Working pape No. 40, IRSEM, Paris Papers.

Bona-Sánchez, C., Pérez-Alemán, J., and Santana-Martín, D. J. (2014), "Politically Connected firms and earnings informativeness in the controlling versus minority shareholders context: European evidence", Corporate Governance: An International Review, Vol. 22 No. 4, pp. 330-346.

Boubakri, N., Mansi, S. A., and Saffar, W. (2013), "Political institutions, connectedness, and corporate risk-taking", Journal of International Business Studies, Vol. 44 No. 3, pp. 195-215.

Boutchkova, M., Doshi, H., Durnev, A., and Molchanov, A. (2012), "Precarius politics and return volatility", Review of Financial Studies, Vol. 25 No. 3, pp. 1111-1154.

Bradbury, M.E., and Scott, T. (2015), "The association between accounting performance and constituent response in political markets", Pacific Accounting Review, Vol. 27 No. 4, pp. 394-410.

Bushman, R., Piotroski, J., and Smith, A. (2004), "What determine corporate transparency", Journal of Accounting Research, Vol. 42 No. 1, pp. 207-252.

Chaney, P. K., Faccio, M., and Parsley, D. (2011), "The quality of accounting information in politically connected firms", Journal of Accounting and Economics, Vol 51 No. 1, pp. 58-76.

Cheng, C. L., Hsu, C. S., and Kung, F. H. (2015), "Political connections, managerial incentives and auditor choice: Evidence from Chin", Pacific Accounting Review, Vol. 27 No. 4, pp. 441-465.

Claessens, S., Feijen, E., and Laeven, L. (2008), "Political connections and preferential access to finance: The role of campaign contributions", Journal of Financial Economics, Vol. 52 No. 6, pp. 2523-2564.

Cohen, S. P. (2002), "The nation ans state of Pakistan", Washington Quarterly, Vol. 25 No. 3, pp. 109122 
Correia, M. M. (2014), "Political connections and SEC enforcement", Journal of Accounting and Economics, Vol. 57 No. 2, pp. 241-262

DeFond, M., and Zhang, J. (2014), "A Review of archival auditing research", Journal of Accounting and Economics, Vol. 58 No. 1, pp. 275-326.

Eleswarapu, V. R., and Venkataraman, K. (2006), "The impact of legal and political institutions on equity trading costs: A cross-country analysis", Review of Financial Studies, Vol. 19 No. 3, pp.1081-1111.

Faccio, M. (2006), "Politically connected firms", The American Economic Review, Vol. 96 No. 1, pp. 369-386.

Faccio, M. (2010), "Differences between politically connected firms: A cross-country analysis", Financial Management, Vol. 10, pp. 905-927

Faccio, M., and Parsley, D. C. (2009), "Sudden deaths: Taking stock of geographic ties", Journal of Financial and Quantitative Analysis, Vol. 44 No. 3, pp. 683-718.

Fair, C. C. (2011), "Why the Pakistan army is here to stay: prospects for governance", International Affairs, Vol. 87 No. 3, pp. 571-588.

Fan, J. P., Wong, T. J., and Zhang, T. (2007), "Politically connected CEOs, corporate governance, and Post-IPO performance of China's newly partially privatized firms", Journal of Financial Economics, Vol. 84 No. 2, pp. 330-357.

Ferguson, T., and Voth, H.-J. (2008), "Betting on Hitler: The value of political connections in Nazi Germany", The Quarterly Journal of Economics, Vol. 123 No. 1, pp.101-137.

Fisman, R. (2001), "Estimating the value of political connections", American Economic Review, Vol. 91 No. 4, pp. 1095-1102.

Gilchrist, S., Sim, J. W., and Zakrajšek, E. (2014), "Uncertainty, financial frictions, and investment dynamics", Working Paper No. w20038, National Bureau of Economic Research.

Glaeser, E. L., and Shleifer, A. (2003), "The rise of the regulatory state", Journal of Economic Literature, Vol. 41 No. 2, pp. 401-425.

Goldman, E., Rocholl, J., and So, J. (2009), "Do politically connected boards affect firm value?", Review of Financial Studies, Vol. 22 No. 6, 2331-2360.

Gregory, S. (2015), "Democratic Transition and Security in Pakistan", Routledge, New York.

Guedhami, O., Pittman, J. A., and Saffar, W. (2014), "Auditor choice in politically connected firms", Journal of Accounting Research, Vol. 52 No. 1, pp. 107-162.

Guenther, D. A., and Young, P. (2000), "The association between financial accounting measures and real economic activity: A multinational study", Journal of Accounting and Economics, Vol. 29 No. 1, pp. 53-72.

Gul, F. A. (2006), "Auditors' response to political connections and cronyism in Malaysia", Journal of Accounting Research, Vol. 44 No. 5, pp. 931-963.

Habib, A., Muhammadi, A.H. and Jiang, H. (2017), "Political connections, related party transactions, and auditor choice: Evidence from Indonesia", Journal of Contemporary Accounting \& Economics, Vol. 13, pp. 1-19.

Habib, A., Ranasinghe, D., Muhammadi, A. H., and Islam, A. (2018), "Political connections, financial reporting and auditing: Survey of the empirical literature", Journal of International Accounting, Auditing and Taxation, Vol. 31, pp. 37-51.

Harymawan, I. (2018), "Why do firms appoint former military personnel as directors? Evidence of loan interest rate in militarily connected firms in Indonesia", Asian Review of Accounting, Vol. 26 No. 1, pp. 2-18.

Harymawan, I. (2020),"Military reforms, military-connected firms and auditor choice", Managerial Auditing Journal, Vol. 35 No. 6, pp. 705-729.

Hasan, A., Hasan, M. K., and Mohammad, S. (2012), "Political patronage and firm performance: Further evidence from Malaysia", Thunderbird International Business Review, Vol. 54 No. 3, 373393.

Heckman, J. J. (1979), "Sample-selection bias as a specification error", Econometrica, Vol. 47, p. 153162.

Houston, W. R., Peters, F. M., and Pratt, H. J. (1999), "The audit risk model, business risk, and audit planning decisions", The Accounting Review, Vol. 74 No. 1, pp. 281-298. 
Houston, W. R., Peters, F. M., and Pratt, H. J. (2005), "Nonlitigation risk and pricing audit services", Auditing: A Journal of Practice \& Theory, Vol. 24 No. 1, pp. 37-53.

International Auditing and Assurance Standards Boards (IAASB). 2014, "A Framework for Audit Quality", International Federation of Accountants.

Jackowicz, K., Kozłowski, Ł., and Mielcarz, P. (2014), "Political connections and operational performance of non-financial firms: New evidence from Poland", Emerging Markets Review, Vol. 20, pp.109-135.

Jens, C. E. (2017), "Political uncertainty and investment: Causal evidence from U.S. gubernatorial elections", Journal of Financial Economics, Vol. 25 No. 1, pp. 15-29.

Johnson, S., and Mitton, T. (2003), "Cronyism and capital controls: evidence from Malaysia", Journal of financial economics, Vol. 124 No. 2017, pp. 563-579.

Jones, J. J. (1991), "Earnings management during import relief invistigation", Journal of Accounitng Research, Vol. 29 No. 2, pp. 193-228.

Julio, B., and Yook, Y. (2012), "Political uncertainty and corporate investment cycles", The Journal of Finance, Vol. 67 No. 1, pp. 45-83.

Kelly, B. T., Pastor, L., and Veronisi, P. (2016), "The price of political uncertainty: Theory and evidence from the option market", Journal of Finance, Vol. 71 No. 5, pp. 2417-2480.

Khan, A. I. (2017, December 19), "Senate wants military's role in commercial activities cut", Daily the Dawn, Retrieved from: https://www.dawn.com/news/1377452

Khwaja, A. I., and Mian, A. (2005), "Do lenders favor politically connected firms? Rent provision in an emerging financial market", The Quarterly Journal of Economics, Vol. 120 No. 4, pp. 13711411.

Kim, Y. and Cannella Jr, A. A. (2008), "Towrads a social capital theory of directors selection", Corporate Governance, Vol. 16 No. 4, pp.182-293.

Lennox, C.S., Francis, J.R., and Wang, Z. (2012), "Selection models in accounting research", The Accounting Review, Vol. 87 No. 2, pp. 589-616.

Manes, E. (2013), "The role of firms", In R. Amjad \& S. J. Burki (Eds.), "Pakistan: Moving the Economy Foreword", pp. 439-480, Lahore, Pakistan: Lahore School of Economics.

Mezzera, M., and Sial, S. (2010), "Media and governance in Pakistan: A controversial yet essential relationship", Netherland: Initiative for Peace Building.

Miller, G. S. (2004), "Disscussion of what determines corporate transparency", Journal of Accounting Reseah, Vol. 42 No. 2004, pp. 253-268.

NAB (2020), "179 x Mega Cases", A list of 179 mega corruption cases submitted by NAB to the Supreme Court of Pakistan. Retrieved from: http://nab.gov.pk/Ops/179\%20x\%20Mega\%20Cases.pdf

Nawaz, S. (2008), "Cross swords: Pakistan, its Army, and the wars within", Oxford University Press, Pakistan.

Niessen, A., and Ruenzi, S. (2010), "Political connectedness and firm performance: Evidence from Germany", German Economic Review, Vol. 11 No. 4, pp. 441-464.

Pastor, L., and Veronesi, P. (2012), "Uncertainty about government policy and stock prices", Journal of Finance, Vol. 67 No. 1, pp. 1219-1264.

Pastor, L., \& Veronesi, P. (2013), "Political uncertainty and risk premia", Journal of Finanancial Economics, Vol. 110 No. 1, pp. 520-545.

Pfeffer, J. and Salancik, G. R. (1978), "The external control of organizations: A resource dependence persepctive", Harpor \& Row, New York

Pintak, L., Bowe, B. J., and Nazir, S. J. (2016), "Mediatization in Pakistan: Perceptions of media influence on a fragile democracy", Journalism, Vol. 19 No. 7, pp. 934-958.

Preuss, S., and Konigsgruber, R. (2021). "How do corporate political connections influence financial reporting? A synthesis of the literature", Journal of Accounting and Public Policy, Vol. 40 No. 1, 106802.

Rajan, R. G., and Zingales, L. (1998), "Which capitalism? Lessons from the East Asian crisis", Journal of Applied Corporate Finance, Vol. 11 No. 3, pp. 40-48.

Ramanna, K., and Roychowdhury, S. (2010), "Elections and discretionary accruals: Evidence from 2004", Journal of Accounting Research, Vol. 48 No. 2, pp. 445-475. 
Redmayne, B. N., Bradbury, E. M., and Cahan, F. S. (2010), "The effect of political visibility on audit effort and audit pricing", Accounting and Finance, Vol. 50 No. 1, pp. 921-939.

Rosenbaum, P. R. and Rubin, D. B. (1983), "The central role of the Propensity Score in observational studies for causal effects", Biometrika, Vol. 70 No. 1, pp.41-55.

Rosenbaum, P. R. and Rubin, D. B. (1985), "Constructing a control group using multivariate matched sampling methods that incorporate the propensity score", The American Statisticians, Vol. 39 No. 1, pp.33-38.

Sadiq, M., Mohammad, S., and Chong, G. K. W. (2019), "Political influences and effective tax rates: Evidence from Pakistan", Dilemas Contemporáneos: Educación, Política y Valores 6

Saeed, A., Belghitar, Y., and Clark, E. (2015), "Political connections and leverage: Firm level evidence from Pakistan", Managerial and Decision Economics, Vol. 36 No. 1, pp. 364-383.

Saeed, A., Belghitar, Y., and Clark, E. (2016), "Do political connections affect firm performance? Evidence from a developing country", Emerging Markets Finance \& Trade, Vol. 52 No. 1, pp. 1876-1891.

Siddiqa, A. (2017), "Military Inc: Inside Pakistan's military economy (2nd Ed.)", Pluto Press, London.

Simunic, D. A. (1980), "The pricing of audit services: Theory and evidence", Journal of Accounting Research, Vol. 18 No. 1, pp. 161-190.

Staniland, P. (2008), "Explaining civil-military relations in complex political environments: India and Pakistan in comparative perspective", Security Studies, Vol. 17 No. 2, pp. 322-362.

Su, Z. Q., Fung, H. G., and Yau, J. (2013), "Political connections and corporate overinvestment: Evidence from China", International Journal of Accounting and Information Management, Vol. 21 No. 4, pp. 285-296

Tee, C. M. (2018),"Family firms, political connections and audit fees: Evidence from Malaysian firms", Managerial Auditing Journal, Vol. 33 No. 6, pp. 613-632.

Wahab, A. A. E, Zain, M. M., and James, K. (2011),"Political connections, corporate governance and audit fees in Malaysia", Managerial Auditing Journal, Vol. 26 No. 5, pp. 393-418.

Wahab, A. A. E., Zain, M. M., and Rahman, A. R. (2015), "Political connections: A threat to auditors independence?", Journal of Accounting in Emerging Economies, Vol. 5 No. 2, pp. 222-246.

Weinbaum, M. G. (1996), "Civic culture and democracy in Pakistan", Asian Survey, Vol. 36 No. 7, 639654.

Yun, Y., and Chun, H. (2021), "Economic policy uncertainty and audit effort: Evidence from audit hours", Managerial Auditing Journal, Vol. 36 No. 4, pp. 643-622.

Zaidi, S. A. (2005), "State, military and social transition: Improbable future of democracy in Pakistan", Economic and Political Weekly,Vol. 40 No. 49, pp. 5173-5181. 
Table 1: Sample Selection Procedures

\begin{tabular}{lr}
\hline Number of non-connected firms (NCON) & 117 \\
Number of civil-connected firms (CCON) & 44 \\
Number of military-connected firms (MCON) & $\underline{23}$ \\
Total number of firms for the period 2003-2014 & $\underline{\mathbf{1 8 4}}$ \\
Maximum firm-year observations (12 years) & 2,208 \\
Less missing control variables: & $\underline{\mathbf{( 9 5 3 )}}$ \\
Final Sample & $\underline{\mathbf{1 , 2 5 5}}$ \\
\hline
\end{tabular}

Table 2: Sample Distribution

Panel A: By Year

\begin{tabular}{rrrrr}
\hline Year & NCON & CCON & MCON & Total \\
\hline 2003 & 14 & 12 & 9 & 35 \\
2004 & 46 & 12 & 10 & 68 \\
2005 & 60 & 18 & 9 & 87 \\
2006 & 72 & 23 & 11 & 106 \\
2007 & 59 & 23 & 14 & 96 \\
2008 & 79 & 27 & 19 & 125 \\
2009 & 72 & 31 & 19 & 122 \\
2010 & 67 & 31 & 20 & 118 \\
2011 & 67 & 33 & 21 & 121 \\
2012 & 71 & 33 & 22 & 126 \\
2013 & 71 & 35 & 22 & 128 \\
2014 & 69 & 33 & 21 & 123 \\
\hline & $\mathbf{7 4 7}$ & $\mathbf{3 1 1}$ & $\mathbf{1 9 7}$ & $\mathbf{1 , 2 5 5}$ \\
\hline
\end{tabular}

Panel B: By Sector

\begin{tabular}{lrrrr}
\hline \multicolumn{1}{c}{ Sector } & NCON & CCON & MCON & TOTAL \\
\hline Automobile and Parts & 4 & 1 & 1 & 6 \\
Chemical & 11 & 2 & 4 & 17 \\
Construction and Materials & 16 & 4 & 2 & 22 \\
Fixed Line Telecom & 2 & 1 & 0 & 3 \\
Food Producers & 24 & 11 & 3 & 38 \\
General Industries & 4 & 3 & 1 & 8 \\
Household Goods & 1 & 0 & 2 & 3 \\
Industrial Engineering & 8 & 2 & 1 & 11 \\
Oil and Gas & 3 & 0 & 1 & 4 \\
Personal Goods (Textile) & 34 & 19 & 6 & 59 \\
Pharma and Bio Tech & 5 & 0 & 0 & 5 \\
Power (Electricity) & 4 & 1 & 1 & 6 \\
Tobacco & 1 & 0 & 1 & 2 \\
\hline & $\mathbf{1 1 7}$ & $\mathbf{4 4}$ & $\mathbf{2 3}$ & $\mathbf{1 8 4}$ \\
\hline
\end{tabular}

Note: $\mathrm{CCON}=1$ for civil-connected firms, 0 otherwise, $\mathrm{MCON}=1$ for military-connected firms, 0 otherwise while $\mathrm{NCON}$ is the non-connected group. 
Table 3: Descriptive Statistics

$\underline{\operatorname{NCON}(\mathrm{N}=747)}$

$\underline{\operatorname{CCON}(N=311)}$

$\underline{\operatorname{MCON}(\mathrm{N}=197)}$

\begin{tabular}{|c|c|c|c|c|c|c|c|c|c|c|c|c|c|c|c|c|c|}
\hline Variable & Mean & $\underline{\text { SD }}$ & $\underline{0.25}$ & Median & $\underline{0.75}$ & Mean & $\underline{\text { SD }}$ & $\underline{0.25}$ & Median & $\underline{0.75}$ & $\underline{\text { Sig\# }}$ & Mean & $\underline{\text { SD }}$ & $\underline{0.25}$ & Median & $\underline{0.75}$ & $\underline{\text { Sig\#\# }}$ \\
\hline LnAF (natural & 6.756 & 1.033 & 5.991 & 6.694 & 7.449 & 6.784 & 1.026 & 5.991 & 6.627 & 7.447 & -0.72 & 6.478 & 0.720 & 6.052 & 6.477 & 6.812 & $2.01^{*}$ \\
\hline${ }^{\prime} \hat{A} F^{\prime}($ Mil. PKR) & 1.508 & 2.065 & 0.400 & 0.808 & 1.718 & 1.560 & 1.991 & 0.400 & 0.755 & 1.714 & -0.72 & 0.871 & 0.928 & 0.425 & 0.650 & 0.909 & $1.98^{*}$ \\
\hline SIZE (natural log) & 8.031 & 1.580 & 6.913 & 8.141 & 9.215 & 8.069 & 1.390 & 7.015 & 8.187 & 9.179 & -0.55 & 7.962 & 1.422 & 6.867 & 7.657 & 8.866 & 0.77 \\
\hline$S I Z E(B \ln . P K R)$ & 8.603 & 6.360 & 1.005 & 3.431 & 10.047 & 7.454 & 1.170 & 1.113 & 3.593 & 9.694 & -0.55 & 8.885 & 1.759 & 0.960 & 2.117 & 7.087 & 0.77 \\
\hline$L E V$ & 0.153 & 0.190 & 0.016 & 0.096 & 0.229 & 0.287 & 0.232 & 0.138 & 0.251 & 0.374 & $11.45^{*}$ & 0.165 & 0.175 & 0.031 & 0.115 & 0.221 & -0.08 \\
\hline$R O A$ & 0.078 & 0.150 & 0.012 & 0.065 & 0.143 & 0.030 & 0.127 & -0.029 & 0.023 & 0.091 & $6.33^{*}$ & 0.089 & 0.138 & 0.009 & 0.073 & 0.150 & 0.77 \\
\hline$R E C$ & 0.214 & 0.140 & 0.117 & 0.180 & 0.275 & 0.169 & 0.097 & 0.095 & 0.158 & 0.226 & $4.33^{*}$ & 0.226 & 0.167 & 0.100 & 0.196 & 0.308 & 0.008 \\
\hline$I N V$ & 0.205 & 0.163 & 0.056 & 0.186 & 0.311 & 0.157 & 0.121 & 0.042 & 0.145 & 0.244 & $3.59^{*}$ & 0.136 & 0.110 & 0.034 & 0.126 & 0.206 & $4.29^{*}$ \\
\hline BIG4 & 0.626 & 0.484 & 0.000 & 1.000 & 1.000 & 0.332 & 0.471 & 0.000 & 0.000 & 1.000 & $73.48^{*}$ & 0.436 & 0.496 & 0.000 & 0.000 & 1.000 & $18.94^{*}$ \\
\hline OPIN & 0.134 & 0.340 & 0.000 & 0.000 & 0.000 & 0.032 & 0.177 & 0.000 & 0.000 & 0.000 & $21.73^{*}$ & 0.015 & 0.122 & 0.000 & 0.000 & 0.000 & $21.07^{*}$ \\
\hline$A C O M$ & 0.985 & 0.120 & 1.000 & 1.000 & 1.000 & 0.977 & 0.148 & 1.000 & 1.000 & 1.000 & 0.811 & 0.989 & 0.100 & 1.000 & 1.000 & 1.000 & $2.953^{*}$ \\
\hline BSIZE & 8.100 & 1.716 & 1.000 & 1.000 & 1.000 & 7.500 & 1.006 & 7.000 & 7.000 & 8.000 & $5.760^{*}$ & 9.223 & 2.977 & 7.000 & 8.000 & 10.000 & $6.863^{*}$ \\
\hline$|D A C|$ & 0.035 & 0.038 & 0.012 & 0.024 & 0.044 & 0.036 & 0.048 & 0.010 & 0.022 & 0.042 & 0.002 & 0.041 & 0.071 & 0.009 & 0.023 & 0.054 & 0.003 \\
\hline
\end{tabular}

Note: Sig\# is the t-statistic for differences between means of non-connected firms (NCON) and civil-connected firms (CCON sample). Sig\#\# is the t-statistic for differences between means of non-connected firms (NCON) and military-connected firms (MCON sample). * is significant at the 0.01 level. $L n A F=$ natural logarithm of audit fees; SIZE

$=$ Natural logarithm of total assets. $L E V$ is long term debts divided by total assets. $R O A$ is calculated as net profits divided by total assets. $R E C$ is accounts receivables scaled by total assets. $I N V$ is inventories scaled by total assets. $B I G 4$ is a dummy variable coded 1 for Big Four audit firms, zero otherwise. OPIN is equal to one if the audit report is modified and zero if it is unqualified. Audit committee $(A C O M)$ is a dummy variable coded 1 for firms with audit committee, 0 otherwise. Board size $(B S I Z E)$ is a continuous variable representing the number of board members. $|D A C|$ is the absolute values of discretionary accruals as explained in footnote 12 . 
Table 4: Correlation Table

\begin{tabular}{|c|c|c|c|c|c|c|c|c|c|c|c|c|c|c|}
\hline Variable & $\operatorname{LnAF}$ & $C C O N$ & $M C O N$ & ELECDUM & SIZE & $L E V$ & $R O A$ & $R E C$ & $I N V$ & $B I G 4$ & OPIN & $A C O M$ & $B S I Z E$ & $|D A C|$ \\
\hline $\operatorname{LnAF}$ & 1.000 & & & & & & & & & & & & & \\
\hline$C C O N$ & 0.047 & 1.000 & & & & & & & & & & & & \\
\hline$M C O N$ & $-0.062 *$ & $-0.237^{*}$ & 1.000 & & & & & & & & & & & \\
\hline ELECDUM & $0.097 *$ & 0.007 & 0.018 & 1.000 & & & & & & & & & & \\
\hline SIZE & $0.719^{*}$ & 0.025 & -0.001 & $0.090 *$ & 1.000 & & & & & & & & & \\
\hline$L E V$ & $-0.164 *$ & $0.250 *$ & 0.004 & $-0.058 *$ & $-0.113^{*}$ & 1.000 & & & & & & & & \\
\hline$R O A$ & $0.283^{*}$ & $-0.149^{*}$ & $0.069^{*}$ & 0.002 & $0.213^{*}$ & $-0.299^{*}$ & 1.000 & & & & & & & \\
\hline$R E C$ & $0.074 *$ & $-0.148^{*}$ & 0.049 & 0.031 & -0.017 & $-0.179^{*}$ & 0.034 & 1.000 & & & & & & \\
\hline$I N V$ & $0.060 *$ & $-0.092 *$ & $-0.108^{*}$ & 0.018 & $-0.091 *$ & $-0.257^{*}$ & $0.117^{*}$ & -0.021 & 1.000 & & & & & \\
\hline$B I G 4$ & $0.471 *$ & $-0.212 *$ & $-0.063^{*}$ & 0.015 & $0.395^{*}$ & $-0.286^{*}$ & $0.370^{*}$ & 0.037 & 0.010 & 1.000 & & & & \\
\hline OPIN & 0.044 & $-0.106^{*}$ & $-0.107^{*}$ & 0.044 & 0.023 & 0.029 & $-0.089 *$ & 0.013 & $-0.086^{*}$ & -0.049 & 1.000 & & & \\
\hline$A C O M$ & $0.055^{*}$ & -0.013 & -0.022 & $0.113 *$ & -0.001 & 0.027 & -0.033 & 0.051 & -0.003 & -0.009 & 0.045 & 1.000 & & \\
\hline BSIZE & $0.264 *$ & $-0.184^{*}$ & $0.252 *$ & 0.004 & $0.303 *$ & $-0.092 *$ & $0.176^{*}$ & $0.180^{*}$ & -0.041 & $0.282 *$ & $-0.060^{*}$ & -0.018 & 1.000 & \\
\hline$|D A C|$ & $0.104 *$ & $0.075^{*}$ & 0.054 & 0.031 & $-0.174 *$ & $-0.062 *$ & $0.107^{*}$ & $0.072 *$ & $0.164 *$ & $-0.069 *$ & 0.017 & 0.044 & $-0.101 *$ & 1.000 \\
\hline
\end{tabular}

Note. The table shows the correlation between the dependent and independent variables, * represents the level of significant at p-value of less than 0.05 . Variable definitions are in notes to Table 3 . 
Table 5: Regression Results

PANEL A: Political connections and audit fees

\begin{tabular}{|c|c|c|c|}
\hline & LnAF & LnAF & LnAF \\
\hline Variables & (1) & (2) & (3) \\
\hline PCON & $\begin{array}{l}-0.048 \\
{[-1.26]}\end{array}$ & & \\
\hline$C C O N$ & & $\begin{array}{c}0.085^{*} \\
{[1.93]}\end{array}$ & $\begin{array}{c}0.013 \\
{[0.20]}\end{array}$ \\
\hline$M C O N$ & & $\begin{array}{c}-0.247 * * * \\
{[-4.82]}\end{array}$ & $\begin{array}{c}-0.225 * * * \\
{[-3.02]}\end{array}$ \\
\hline SIZE & $\begin{array}{c}0.374 * * * \\
{[28.54]}\end{array}$ & $\begin{array}{c}0.362 * * * \\
{[27.71]}\end{array}$ & $\begin{array}{c}0.363 * * * \\
{[27.74]}\end{array}$ \\
\hline$L E V$ & $\begin{array}{l}-0.049 \\
{[-0.58]}\end{array}$ & $\begin{array}{l}-0.107 \\
{[-1.28]}\end{array}$ & $\begin{array}{c}-0.277 * * \\
{[-2.26]}\end{array}$ \\
\hline$R O A$ & $\begin{array}{c}0.489 * * * \\
{[3.91]}\end{array}$ & $\begin{array}{c}0.550 * * * \\
{[4.43]}\end{array}$ & $\begin{array}{c}0.673 * * * \\
{[4.49]}\end{array}$ \\
\hline$C C O N^{*} L E V$ & & & $\begin{array}{c}0.353^{*} \\
{[1.95]}\end{array}$ \\
\hline$C C O N^{*} R O A$ & & & $\begin{array}{l}-0.282 \\
{[-0.94]}\end{array}$ \\
\hline$M C O N^{*} L E V$ & & & $\begin{array}{c}0.222 \\
{[0.98]}\end{array}$ \\
\hline$M C O N^{*} R O A$ & & & $\begin{array}{c}-0.747 * * \\
{[-2.20]}\end{array}$ \\
\hline$R E C$ & $\begin{array}{c}0.310 * * \\
{[2.39]}\end{array}$ & $\begin{array}{c}0.297 * * \\
{[2.32]}\end{array}$ & $\begin{array}{c}0.297 * * \\
{[2.31]}\end{array}$ \\
\hline$I N V$ & $\begin{array}{c}0.825 * * * \\
{[6.59]}\end{array}$ & $\begin{array}{c}0.750 * * * \\
{[6.03]}\end{array}$ & $\begin{array}{c}0.699 * * * \\
{[5.55]}\end{array}$ \\
\hline$B I G 4$ & $\begin{array}{c}0.373 * * * \\
{[8.96]}\end{array}$ & $\begin{array}{c}0.371 * * * \\
{[9.04]}\end{array}$ & $\begin{array}{c}0.365 * * * \\
{[8.86]}\end{array}$ \\
\hline OPIN & $\begin{array}{l}-0.061 \\
{[-1.03]}\end{array}$ & $\begin{array}{l}-0.060 \\
{[-1.03]}\end{array}$ & $\begin{array}{l}-0.058 \\
{[-0.99]}\end{array}$ \\
\hline$A C O M$ & $\begin{array}{c}0.173 \\
{[1.34]}\end{array}$ & $\begin{array}{l}0.176 \\
{[1.38]}\end{array}$ & $\begin{array}{c}0.189 \\
{[1.48]}\end{array}$ \\
\hline BSIZE & $\begin{array}{c}0.012 \\
{[1.14]}\end{array}$ & $\begin{array}{c}0.027 * * \\
{[2.53]}\end{array}$ & $\begin{array}{c}0.029 * * * \\
{[2.64]}\end{array}$ \\
\hline$|D A C|$ & $\begin{array}{c}0.240 \\
{[0.82]}\end{array}$ & $\begin{array}{c}0.334 \\
{[1.15]}\end{array}$ & $\begin{array}{c}0.419 \\
{[1.44]}\end{array}$ \\
\hline Constant & $\begin{array}{c}2.503 * * * \\
{[10.10]}\end{array}$ & $\begin{array}{c}2.501 * * * \\
{[10.21]}\end{array}$ & $\begin{array}{c}2.476^{* * *} \\
{[10.04]}\end{array}$ \\
\hline Observations & 1,255 & 1,255 & 1,255 \\
\hline Adj. $R^{2}$ & 69.57 & 70.35 & 70.51 \\
\hline Industry FE & Yes & Yes & Yes \\
\hline Year FE & Yes & Yes & Yes \\
\hline
\end{tabular}


PANEL B: Political uncertainty, political connections and audit fees

\begin{tabular}{|c|c|c|c|c|c|}
\hline & LnAF & LnAF & & LnAF & LnAF \\
\hline Variables & (1) & (2) & Variables & (3) & (4) \\
\hline \multirow{2}{*}{$C C O N$} & & $0.125^{* *}$ & CCON & & -0.061 \\
\hline & & {$[2.22]$} & & & {$[-0.23]$} \\
\hline \multirow[t]{2}{*}{$M C O N$} & & $-0.167 * *$ & $M C O N$ & & 0.194 \\
\hline & & {$[-2.53]$} & & & {$[0.63]$} \\
\hline \multirow[t]{2}{*}{ ELECDUM } & $0.188 * * *$ & $0.199 * * *$ & PIindex & $0.966^{* * *}$ & $0.990 * * *$ \\
\hline & [4.67] & {$[4.04]$} & & {$[6.32]$} & {$[5.81]$} \\
\hline \multirow[t]{2}{*}{$C C O N^{*} E L E C D U M$} & & -0.022 & $C C O N^{*}$ PIindex & & 0.059 \\
\hline & & {$[-0.27]$} & & & {$[0.56]$} \\
\hline \multirow[t]{2}{*}{$M C O N^{*} E L E C D U M$} & & -0.009 & MCON*PIindex & & -0.179 \\
\hline & & {$[-0.09]$} & & & {$[-1.46]$} \\
\hline \multirow[t]{2}{*}{ SIZE } & $0.413 * * *$ & $0.404 * * *$ & SIZE & $0.372 * * *$ & $0.362 * * *$ \\
\hline & {$[30.58]$} & {$[29.53]$} & & {$[28.55]$} & {$[27.67]$} \\
\hline \multirow[t]{2}{*}{ LEV } & -0.037 & -0.086 & $L E V$ & -0.060 & -0.106 \\
\hline & {$[-0.42]$} & {$[-0.96]$} & & {$[-0.72]$} & {$[-1.27]$} \\
\hline \multirow[t]{2}{*}{$R O A$} & $0.470 * * *$ & $0.519 * * *$ & $R O A$ & $0.493 * * *$ & $0.557 * * *$ \\
\hline & {$[3.52]$} & {$[3.90]$} & & {$[3.95]$} & {$[4.49]$} \\
\hline \multirow[t]{2}{*}{$R E C$} & $0.593 * * *$ & $0.590 * * *$ & $R E C$ & $0.321^{* *}$ & $0.313^{* *}$ \\
\hline & {$[4.34]$} & [4.34] & & {$[2.48]$} & {$[2.44]$} \\
\hline \multirow[t]{2}{*}{$I N V$} & $0.932 * * *$ & $0.870 * * *$ & $I N V$ & $0.852 * * *$ & $0.758 * * *$ \\
\hline & {$[7.07]$} & {$[6.52]$} & & {$[6.90]$} & {$[6.09]$} \\
\hline \multirow[t]{2}{*}{$B I G 4$} & $0.331 * * *$ & $0.329 * * *$ & $B I G 4$ & $0.386^{* * *}$ & $0.372 * * *$ \\
\hline & {$[7.71]$} & {$[7.47]$} & & {$[9.57]$} & {$[9.07]$} \\
\hline \multirow[t]{2}{*}{ OPIN } & 0.080 & 0.083 & OPIN & -0.041 & -0.062 \\
\hline & {$[1.32]$} & {$[1.35]$} & & {$[-0.72]$} & {$[-1.07]$} \\
\hline \multirow[t]{2}{*}{$A C O M$} & $0.422 * * *$ & $0.432 *$ & $A C O M$ & 0.175 & 0.161 \\
\hline & {$[3.10]$} & {$[3.20]$} & & {$[1.35]$} & {$[1.26]$} \\
\hline \multirow[t]{2}{*}{$B S I Z E$} & 0.003 & 0.016 & BSIZE & 0.010 & $0.026^{* *}$ \\
\hline & {$[0.23]$} & {$[1.34]$} & & {$[0.98]$} & {$[2.37]$} \\
\hline \multirow[t]{2}{*}{$|D A C|$} & 0.294 & 0.367 & $|D A C|$ & 0.235 & 0.339 \\
\hline & {$[0.94]$} & [1.18] & & {$[0.80]$} & [1.17] \\
\hline \multirow[t]{2}{*}{ INFLATION } & $0.026^{* * *}$ & $0.027 * * *$ & & & \\
\hline & {$[2.73]$} & {$[2.82]$} & & & \\
\hline \multirow[t]{2}{*}{ GDP_GROWTH } & $-0.017 * * *$ & $-0.017 * * *$ & & & \\
\hline & {$[-2.93]$} & {$[-2.92]$} & & & \\
\hline \multirow[t]{2}{*}{ Constant } & $2.129 * * *$ & $2.092 * * *$ & Constant & $0.968^{* *}$ & $0.925^{* *}$ \\
\hline & [8.19] & [8.09] & & {$[2.44]$} & {$[2.13]$} \\
\hline Observations & 1,255 & 1,255 & Observations & 1,255 & 1,255 \\
\hline Adj. $R^{2}$ & 65.07 & 65.55 & Adj. $R^{2}$ & 69.57 & 70.38 \\
\hline Industry FE & Yes & Yes & Industry FE & Yes & Yes \\
\hline Year FE & No & No & Year FE & Yes & Yes \\
\hline
\end{tabular}

Note: Variable definitions are in notes to Table 3 except INFLATION, the rate of inflation in the current year, and GDP_GROWTH, the percentage increase in GDP in the current year as compared with the previous year. Both these variables are retrieved from the official website of the World Bank. t-statistics in brackets. *** $\mathrm{p}<0.01, * *$ $\mathrm{p}<0.05$. 
Table 6: Regression Results political connections/political uncertainty and audit fees after implementing PSM technique

PANEL A: Variables diagnostic i.e., differences between the means of matched samples

\begin{tabular}{|c|c|c|c|c|c|c|c|c|c|c|c|c|c|c|c|c|c|c|}
\hline \multirow[b]{3}{*}{ Variables } & \multicolumn{6}{|c|}{ CCON Sample } & \multicolumn{6}{|c|}{ MCON Sample } & \multicolumn{6}{|c|}{ Election Years Sample } \\
\hline & \multicolumn{3}{|c|}{ Pre-Matching } & \multicolumn{3}{|c|}{ Post-Matching } & \multicolumn{3}{|c|}{ Pre-Matching } & \multicolumn{3}{|c|}{ Post-Matching } & \multicolumn{3}{|c|}{ Pre-Matching } & \multicolumn{3}{|c|}{ Post-Matching } \\
\hline & Treated & Control & Sig & Treated & Control & Sig & Treated & Control & Sig & Treated & Control & Sig & Treated & Control & Sig & Treated & Control & Sig \\
\hline SIZE & 7.984 & 7.829 & 1.49 & 7.984 & 7.728 & 1.57 & 7.998 & 7.996 & -0.28 & 7.998 & 8.048 & -0.22 & 8.162 & 7.947 & $2.45^{* *}$ & 8.162 & 8.212 & -0.55 \\
\hline$L E V$ & 0.285 & 0.164 & $5.74^{* * *}$ & 0.285 & 0.303 & -0.89 & 0.197 & 0.194 & 0.34 & 0.197 & 0.158 & 1.38 & 0.178 & 0.204 & $-2.31^{* *}$ & 0.178 & 0.195 & -1.47 \\
\hline$R O A$ & 0.021 & 0.075 & $-5.69^{* * *}$ & 0.021 & 0.003 & 1.43 & 0.089 & 0.058 & $2.74^{* *}$ & 0.089 & 0.080 & 0.46 & 0.069 & 0.067 & 0.24 & 0.069 & 0.069 & -0.05 \\
\hline$R E C$ & 0.173 & 0.205 & $-3.57^{* * *}$ & 0.173 & 0.157 & 1.14 & 0.229 & 0.202 & $2.15^{*}$ & 0.229 & 0.218 & 0.48 & 0.210 & 0.202 & 0.95 & 0.210 & 0.203 & 0.78 \\
\hline$I N V$ & 0.168 & 0.194 & $2.63^{* *}$ & 0.168 & 0.136 & $2.01^{* *}$ & 0.141 & 0.194 & $-2.08^{* *}$ & 0.141 & 0.174 & -1.46 & 0.186 & 0.181 & 0.56 & 0.186 & 0.178 & 0.85 \\
\hline$B I G 4$ & 0.281 & 0.546 & $-7.90^{* * *}$ & 0.281 & 0.244 & 0.73 & 0.464 & 0.508 & $-1.85^{*}$ & 0.464 & 0.442 & 0.31 & 0.534 & 0.518 & 0.55 & 0.534 & 0.509 & 0.78 \\
\hline OPIN & 0.035 & 0.126 & $-4.33^{* * *}$ & 0.035 & 0.042 & -0.21 & 0.017 & 0.106 & $-4.08^{* * *}$ & 0.017 & 0.020 & -0.09 & 0.102 & 0.085 & 1.05 & 0.102 & 0.112 & -0.52 \\
\hline$A C O M$ & 0.976 & 0.987 & -1.28 & 0.976 & 0.993 & -1.29 & 0.989 & 0.984 & 0.57 & 0.989 & 0.988 & 0.04 & 1.000 & 1.000 & 0.00 & 1.000 & 1.000 & 0.00 \\
\hline BSIZE & 7.399 & 7.792 & $-5.79^{* * *}$ & 7.399 & 7.410 & -0.07 & 9.171 & 7.895 & $5.03^{* * *}$ & 9.171 & 9.678 & -1.64 & 8.142 & 8.130 & 0.11 & 8.142 & 8.101 & 0.29 \\
\hline$|D A C|$ & 0.034 & 0.002 & $-3.44^{* * *}$ & 0.034 & 0.034 & 0.11 & 0.036 & 0.038 & -0.54 & 0.036 & 0.033 & 0.54 & 0.037 & 0.035 & 0.41 & 0.037 & 0.33 & 0.69 \\
\hline
\end{tabular}


PANEL B: Audit Fees regression results for political connections and political uncertainty on audit fees after implementing the PSM Technique

\begin{tabular}{|c|c|c|c|c|c|c|c|c|c|c|}
\hline & $\mathrm{CCON}$ & LnAF & LnAF & MCON & LnAF & LnAF & & ELECDUM & LnAF & LnAF \\
\hline Variables & (1) & $(2)$ & (3) & (4) & (5) & (6) & Variables & (7) & (8) & (9) \\
\hline CCON & 8 & $\begin{array}{c}0.109 * * \\
{[2.56]}\end{array}$ & $\begin{array}{l}0.065 \\
{[1.04]}\end{array}$ & & & & $C C O N$ & & & $\begin{array}{c}0.164 * * \\
{[2.29]}\end{array}$ \\
\hline$M C O N$ & & & & & $\begin{array}{c}-0.327 * * * \\
{[-5.50]}\end{array}$ & $\begin{array}{c}-0.365^{* * *} \\
{[-5.60]}\end{array}$ & $M C O N$ & & & $\begin{array}{c}-0.294 * * * \\
{[-3.34]}\end{array}$ \\
\hline$L E V$ & $\begin{array}{c}1.019 * * * \\
{[4.55]}\end{array}$ & $\begin{array}{l}0.038 \\
{[0.45]}\end{array}$ & $\begin{array}{l}-0.015 \\
{[-0.14]}\end{array}$ & $\begin{array}{l}-0.288 \\
{[-1.16]}\end{array}$ & $\begin{array}{l}0.007 \\
{[0.05]}\end{array}$ & $\begin{array}{l}0.100 \\
{[0.61]}\end{array}$ & ELECDUM & & $\begin{array}{c}0.196 * * * \\
{[4.13]}\end{array}$ & $\begin{array}{c}0.211 * * * \\
{[3.70]}\end{array}$ \\
\hline$R O A$ & $\begin{array}{c}-0.094 * * * \\
{[-2.73]}\end{array}$ & $\begin{array}{l}0.046 \\
{[0.39]}\end{array}$ & $\begin{array}{l}-0.044 \\
{[-0.34]}\end{array}$ & $\begin{array}{l}0.816^{*} \\
{[1.78]}\end{array}$ & $\begin{array}{l}0.195 \\
{[0.71]}\end{array}$ & $\begin{array}{l}0.264 \\
{[0.91]}\end{array}$ & $L E V$ & $\begin{array}{c}-0.412 * * \\
{[-2.04]}\end{array}$ & $\begin{array}{l}-0.127 \\
{[-1.15]}\end{array}$ & $\begin{array}{c}-0.190^{*} \\
{[-1.71]}\end{array}$ \\
\hline$C C O N^{*} L E V$ & & & $\begin{array}{l}0.125 \\
{[0.79]}\end{array}$ & & & & $R O A$ & $\begin{array}{l}-0.139 \\
{[-0.47]}\end{array}$ & $\begin{array}{c}0.486 * * * \\
{[3.14]}\end{array}$ & $\begin{array}{c}0.503 * * * \\
{[3.28]}\end{array}$ \\
\hline$C C O N^{*} R O A$ & & & $\begin{array}{l}0.461 \\
{[1.58]}\end{array}$ & & & & $C C O N^{*} E L E C D U M$ & & & $\begin{array}{l}-0.076 \\
{[-0.82]}\end{array}$ \\
\hline$M C O N^{*} L E V$ & & & & & & $\begin{array}{l}-0.355 \\
{[-1.20]}\end{array}$ & $M C O N^{*} E L E C D U M$ & & & $\begin{array}{l}0.115 \\
{[1.03]}\end{array}$ \\
\hline$M C O N^{*} R O A$ & & & & & & $\begin{array}{l}-0.586 \\
{[-0.64]}\end{array}$ & & & & \\
\hline Constant & $\begin{array}{l}-0.229 \\
{[-0.34]}\end{array}$ & $\begin{array}{c}2.897 * * * \\
{[9.71]}\end{array}$ & $\begin{array}{c}2.912 * * * \\
{[9.77]}\end{array}$ & $\begin{array}{l}-0.229 \\
{[-0.34]}\end{array}$ & $\begin{array}{c}-2.595^{* * *} \\
{[-3.47]}\end{array}$ & $\begin{array}{c}1.982 * * * \\
{[4.06]}\end{array}$ & Constant & $\begin{array}{c}-1.009 * * \\
{[-2.31]}\end{array}$ & $\begin{array}{c}2.295 * * * \\
{[7.86]}\end{array}$ & $\begin{array}{c}2.228 * * * \\
{[7.71]}\end{array}$ \\
\hline Control Variables & Yes & Yes & Yes & Yes & Yes & Yes & Control Variables & Yes & Yes & Yes \\
\hline Observations & 1,166 & 576 & 576 & 1,049 & 394 & 394 & Observations & 1,235 & 958 & 958 \\
\hline Pseudo/Adj. $\mathrm{R}^{2}$ & 22.26 & 75.05 & 75.10 & 26.28 & 75.25 & 75.27 & Pseudo/Adj. $\mathrm{R}^{2}$ & 01.14 & 65.26 & 66.08 \\
\hline Industry FE & Yes & Yes & Yes & Yes & Yes & Yes & Industry FE & Yes & Yes & Yes \\
\hline Year FE & No & Yes & Yes & No & Yes & Yes & Year FE & No & No & No \\
\hline
\end{tabular}

Note: Variable definitions are in notes to Table 3. t-statistics in brackets. ${ }^{* * *} \mathrm{p}<0.01,{ }^{* *} \mathrm{p}<0.05,{ }^{*} \mathrm{p}<0.10$. 
Table 7: Audit Fees regression results for political connections/ political uncertainty after implementing Two-Stage Heckman Selection Procedures

\begin{tabular}{|c|c|c|c|c|c|c|c|c|c|}
\hline & PCON & LnAF & LnAF & & LnAF & LnAF & & LnAF & LnAF \\
\hline Variables & (1) & (2) & (3) & Variables & (4) & (5) & Variables & (6) & (7) \\
\hline \multirow[t]{2}{*}{$C C O N$} & & 0.025 & 0.014 & $C C O N$ & & 0.065 & CCON & & -0.130 \\
\hline & & {$[0.21]$} & {$[0.11]$} & & & {$[0.49]$} & & & {$[-0.47]$} \\
\hline \multirow[t]{2}{*}{$M C O N$} & & $-0.300 * * *$ & $-0.224 *$ & $M C O N$ & & $-0.220^{*}$ & $M C O N$ & & 0.145 \\
\hline & & {$[-2.66]$} & {$[-1.77]$} & & & {$[-1.74]$} & & & {$[0.47]$} \\
\hline \multirow[t]{2}{*}{$L E V$} & $0.817 * * *$ & -0.091 & $-0.277 * * *$ & ELECDUM & $0.188 * * *$ & $0.200 * * *$ & PIindex & $0.950 * * *$ & $0.992 * * *$ \\
\hline & {$[3.92]$} & {$[-1.04]$} & {$[-2.18]$} & & {$[4.74]$} & {$[4.09]$} & & {$[6.61]$} & {$[5.92]$} \\
\hline \multirow[t]{2}{*}{$R O A$} & $-0.624 *$ & $0.544 * * *$ & $0.673 * * *$ & $C C O N^{*} E L E C D U M$ & & -0.021 & $C C O N^{*}$ PIindex & & 0.057 \\
\hline & {$[-1.91]$} & {$[4.43]$} & {$[4.55]$} & & & {$[-0.26]$} & & & {$[0.55]$} \\
\hline \multirow[t]{2}{*}{$C C O N^{*} L E V$} & & & $0.353 * *$ & $M C O N^{*} E L E C D U M$ & & -0.010 & MCON*PIindex & & -0.187 \\
\hline & & & [1.98] & & & {$[-0.10]$} & & & {$[-1.54]$} \\
\hline \multirow[t]{2}{*}{$C C O N^{*} R O A$} & & & 0.223 & & & & & & \\
\hline & & & {$[1.00]$} & & & & & & \\
\hline \multirow[t]{2}{*}{$M C O N^{*} L E V$} & & & -0.282 & & & & & & \\
\hline & & & {$[-0.95]$} & & & & & & \\
\hline \multirow[t]{2}{*}{$M C O N^{*} R O A$} & & & $-0.748 * *$ & & & & & & \\
\hline & & & {$[-2.22]$} & & & & & & \\
\hline \multirow[t]{2}{*}{ CAPITAL } & $1.145^{* * *}$ & & & & & & & & \\
\hline & {$[8.95]$} & & & & & & & & \\
\hline \multirow[t]{2}{*}{$I M R$} & & -0.001 & -0.001 & $I M R$ & 0.101 & 0.037 & $I M R$ & 0.110 & 0.047 \\
\hline & & {$[-0.01]$} & {$[-0.01]$} & & [1.34] & {$[0.49]$} & & {$[1.56]$} & {$[0.67]$} \\
\hline \multirow[t]{2}{*}{ Constant } & $-3.557 * * *$ & $2.488 * * *$ & $2.476^{* * *}$ & Constant & $2.091 * * *$ & $2.079 * * *$ & Constant & $0.965 * *$ & $0.902 * *$ \\
\hline & {$[-5.49]$} & [10.26] & [10.16] & & [8.05] & {$[8.10]$} & & {$[2.46]$} & {$[2.11]$} \\
\hline Control Variables & Yes & Yes & Yes & Control Variables & Yes & Yes & Control Variables & Yes & Yes \\
\hline Observations & 1,255 & 1,255 & 1,255 & Observations & 1,255 & 1,255 & Observations & 1,255 & 1,255 \\
\hline Industry FE & Yes & Yes & Yes & Industry FE & Yes & Yes & Industry FE & Yes & Yes \\
\hline Year FE & No & Yes & Yes & Year FE & No & No & Year FE & Yes & Yes \\
\hline
\end{tabular}

Note: Variable definitions are in notes to Table 3, except CAPITAL and IMR, where CAPITAL is a dummy variable equal 1 for firms located in the capital city, or otherwise. IMR is the inverse mills ratio calculated by running the first stage probit regression. t-statistics in brackets. $* * * \mathrm{p}<0.01, * * \mathrm{p}<0.05, * \mathrm{p}<0.10$. 
Appendix 1 Regime Changes in Pakistan

\begin{tabular}{|c|c|c|c|c|}
\hline & Head of State & Designation & Tenure & Regime \\
\hline 1 & Muhammad Ali Jinnah & 14/08/1947 To $11 / 09 / 1948$ & Y: 01, M: 01, D: 28 & Civil \\
\hline \multicolumn{5}{|c|}{ Detail: The first governor general and the founder of Pakistan; died on September 1, 1948.} \\
\hline 2 & Liaqat Ali Khan & 11/09/1948 To $13 / 11 / 1948$ & Y: 00, M: 02, D: 02 & Civil \\
\hline \multicolumn{5}{|c|}{ Detail: The new governor general took oath on November 13, 1948} \\
\hline 3 & Khawaja Nazimuddin & 13/11/1948 To $17 / 10 / 1951$ & Y: 00, M: 11, D: 04 & Civil \\
\hline \multicolumn{5}{|c|}{ Detail: He resigned from the position on November 13,1948 and took charge as prime minister of the country on the same day. } \\
\hline 4 & mmad & $19 / 10 / 1951 \mathrm{~T}$ & Y: 03, M: 09, D: 19 & Civil \\
\hline
\end{tabular}

Detail: He left on leave of illness and appointed Iskander Mirza as acting governor general. He was dismissed by the acting governor general while on leave.
5 Iskander Mirza
Governor General
07/08/1955 To $23 / 03 / 1956$
Y: 00, M: 07, D: 16
Civil

Detail: The post of governor general was replaced by the president after the promulgation of the first Constitution of Pakistan. He left the office to become the President of Pakistan.

\begin{tabular}{llllll}
\hline 6 & Iskander Mirza & President & 23/03/1956 To 27/10/1958 & Y: 02, M: 07, D: 04 Civil
\end{tabular}

Detail: He was removed from the office after a successful coup by the military.
7 General Ayub Khan
Martial Law
$27 / 10 / 1958$ To $25 / 03 / 1969$
Y: 10, M: 04, D: 29
Military

Administrator

Detail: General Ayub Khan resigned after pressure from the opposition and public in response to rising prices of commodities in the country.

\begin{tabular}{lllll}
\hline $\mathbf{G}$ & General Yahya Khan & $\begin{array}{l}\text { Martial Law } \\
\text { Administrator }\end{array}$ & 25/03/1969 To 20/12/1971 & Y: 02, M: 08, D: 26
\end{tabular}

Detail: General Yahya resigned after defeat in the 1971 War with India and the separation of East Pakistan.

9 Zulfiqar Ali Bhutto $\quad$ President $\quad 20 / 12 / 1971$ To 13/08/1973 $\quad$ Y: 01, M: 07, D: 24 Civil

Detail: Bhutto resigned to become the Prime Minister after 1973 was promulgated, which established a parliamentary form of government.

10 Zulfiqar Ali Bhutto $\quad$ Prime Minister $\quad$ 14/08/1973 To 05/07/1977 $\quad$ Y: 03, M: 10, D: $21 \quad$ Civil

Detail: The Prime Minister was sacked by the then Chief of Army Staff Gen. Zia after a successful coup d'état. Mr. Bhutto was then hanged on the charge of murdering of one of his ex-party members.
11 General Zia-ul-Haq
Martial Law
05/07/1977 To $17 / 08 / 1988$
Y: 01, M: 01, D: 28
Military
Administrator

Detail: The General was killed in a mysterious bomb blast in his plane on August 17, 1988.

12 Ghulam Ishaq Khan $\quad$ President $\quad 17 / 08 / 1988$ To 02/12/1988 $\quad$ Y: 00, M: 03, D: 15 Interim

Detail: He became the president after the death of the military dictator and remained in the office until 18 July 1993 . Benazir Bhutto became head of the state after winning the general elections held in 1988.

13 Benazir Bhutto $\quad$ Prime Minister $\quad 02 / 12 / 1988$ To 06/08/1990 $\quad$ Y: 01, M: 08, D: 04 Civil

Detail: Her government was dismissed by the President Ghulam Ishaq Khan on charges of corruption, mismanagement, and high unemployment levels.

14 Ghulam Mustafa Jatoi $\quad$ Prime Minister $\quad$ 06/08/1990 To 06/11/1990 $\quad$ Y: 00, M: 03, D: 00 Caretaker

Detail: He left the office after the elected Prime Minister took charge of the office.
15 Nawaz Sharif
Prime Minister
06/11/1990 To 18/04/1993
Y: 02, M: 05, D: 12
Civil

Detail: His government was dissolved by the President Ghulam Ishaq Khan on the charges of corruption and mismanagement. However, he was reinstated by the Supreme Court in May the same year.
16 Balakh Sher Mazari
Prime Minister
18/04/1993 To 26/05/1993
Y: 00, M: 01, D: 08
Caretaker

Detail: He was appointed as caretaker Prime Minister by the president of Pakistan after sacking the elected government of Prime Minister Nawaz Sharif.
17 Nawaz Sharif
Prime Minister
26/05/1993 To 18/07/1993
Y: 00, M: 01, D: 22
Civil

Detail: After his reinstatement by the Supreme Court, the relations between him and the President deteriorated and, consequently, both were forced by the Army Chief to resign.

\begin{tabular}{llccc}
\hline 18 & Moeenuddin Qureshi & Prime Minister & 18/07/1993 To 19/10/1993 & Y: 00, M: 03, D: 01 \\
Detail: He left the office after the elected Prime Minister took charge of the office. & \\
\hline
\end{tabular}




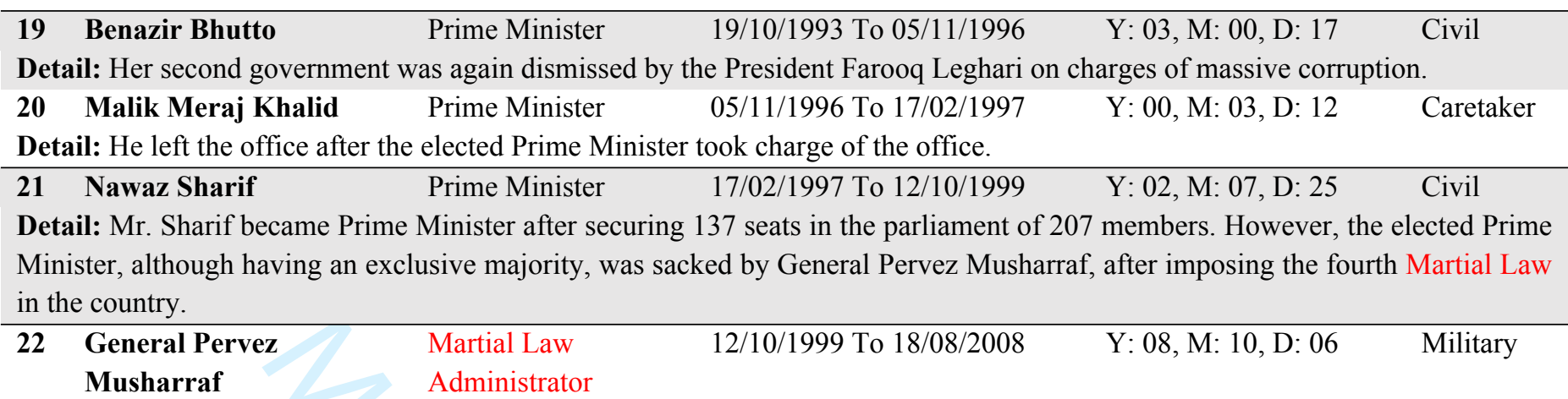

Detail: As per article 6 of the constitution of Pakistan, anyone who abrogates, suspends, or conspires against the elected government shall be guilty of high treason. High treason is punishable as per the constitution. Musharraf resigned to avoid impeachment, as the key opposition parties were demanding his impeachment according to article 6 of the constitution.

23 Yousaf Raza Gillani $\quad$ Prime Minister $\quad$ 25/03/2008 To 26/04/2012 $\quad$ Y: 04, M: 01, D: 02 Civil

Detail: Mr. Gillani was nominated as Prime Minister by the Central Executive Committee of Pakistan People's Party. On 26 April 2012, Mr. Gillani was convicted on charges of contempt of court by the Supreme Court of Pakistan for refusing to bring charges against President Asif Ali Zardari. He was sentenced to be held under custody until the adjournment of the court. This symbolic sentence resulted in the resignation of Prime Minister.

24 Raja Pervaiz Ashraf $\quad$ Prime Minister $\quad$ 22/06/1912 To 25/03/2013 $\quad$ Y: 00, M: 09, D: 03 Civil

After the conviction of Prime Minister Gillani, Raja Pervez Ashraf was elected as Prime Minister on 22 Jun. 2012. His election as Prime Minister ended the 2 months turmoil where the country was without any elected Prime Minister.

\begin{tabular}{lccccc}
\hline $\mathbf{2 5}$ & Mir Khazar Khoso & Prime Minister & 25/03/2013 To 05/06/2013 & Y: 00, M: 02, D: 11 & Caretaker \\
Detail: He left the office after the elected Prime Minister took charge of the office. & \\
\hline 26 & Nawaz Sharif & Prime Minister & 05/06/2013 To 28/07/2017 & Y: 04, M: 01, D: 22 & Civil
\end{tabular}

Detail: His election as Prime Minister was a historical moment for Pakistan. A civilian government handed over the reins of power to another civilian government for the first time in the history of politically volatile Pakistan. An investigation of Sharif's family alleged corruption and tax evasion started after the leak of financial dealings of Panama law firm Mossck Fonesca (Panama papers) on April 4, 2016. Panama papers linked the Prime Minister's children to the purchase of a property in London through an offshore company based in British Virgin Islands. The Panama papers case ended in the disqualification of Prime Minister Nawaz Sharif by the Supreme Court of Pakistan. The court disqualified the Prime Minister for being dishonest by not disclosing his employment in one of his son's firms based in Dubai.

\begin{tabular}{lcc}
\hline & Total Period & Average Period Per Regime \\
\hline Civil Regime & Y: 35, M: 09, D: 15 & Y: 02, M: 02, D: 16 \\
Military Regime & Y: 32, M: 01, D: 13 & Y: 08, M: 00, D: 11 \\
\hline
\end{tabular}




\title{
Political connections, political uncertainty and audit fees: evidence from Pakistan
}

\author{
Ahmad, F \\ 2022-01-21 \\ 22/04/2023 - Downloaded from MASSEY RESEARCH ONLINE
}

